\begin{tabular}{ll}
\multicolumn{1}{c}{ ABSTRACT } \\
Title of thesis: & COMPLIANCE WITH AGE AT INITIATION OF HUMAN \\
PAPILLOMAVIRUS VACCINE SERIES BY SOCIOECONOMIC \\
STATUS, RACE/ETHNICITY, AND HEALTH INSURANCE \\
COVERAGE AMONG 13-17 YEAR-OLD FEMALES WHO \\
RECEIVED AT LEAST ONE HPV VACCINE SHOT: UNITED \\
STATES, 2011
\end{tabular}

Kanokphan Rattanawatkul, Masters of Public Health, 2014

Thesis directed by: Associate Professor Olivia Carter-Pokras

Department of Epidemiology and Biostatistics

Human Papillomavirus (HPV) vaccine has been shown to prevent cervical cancer.

Numerous studies have examined factors associated with HPV vaccine series initiation, but little is known about factors associated with age of initiation of HPV vaccine. Using cross-sectional data from the 2011 National Immunization Survey-Teen, this study examined the relationship between Advisory Committee on Immunization Practices' recommended age at initiation of the HPV vaccine series and socioeconomic status, race/ethnicity, and health insurance among 13-17 year-old females who received at least one HPV vaccine shot $(n=5,965)$. On-time initiation of HPV vaccine series was significantly associated with having public health insurance (AOR:

1.825, 95\% CI: 1.266, 2.631). Females with college-graduated mothers (AOR: $0.669,95 \%$ CI: $0.487,0.918$ ) or household income greater than $\$ 75,000$ (AOR: $0.746,95 \%$ CI: $0.568,0.98$ ) were less likely to initiate on-time. Research is needed to further investigate the reasons for late initiation among these subgroups. 


\section{COMPLIANCE WITH AGE AT INITIATION OF HUMAN PAPILLOMAVIRUS VACCINE SERIES BY SOCIOECONOMIC STATUS, RACE/ETHNICITY, AND HEALTH INSURANCE COVERAGE AMONG 13-17 YEAR-OLD FEMALES WHO RECEIVED AT LEAST ONE HPV VACCINE SHOT: UNITED STATES, 2011}

By

Kanokphan Rattanawatkul

Thesis submitted to the Faculty of the Graduate School of University of Maryland, College Park in partial fulfillment of the requirements for the degree of

Masters in Public Health

2014

Advisory Committee:

Associate Professor Olivia Carter-Pokras, Chair

Assistant Professor Jie Chen

Assistant Professor Xin He

Professor Mei-Ling Ting Lee 
(C) Copyright by

Kanokphan Rattanawatkul

2014 


\section{ACKNOWLEDGEMENTS}

I would like to express special appreciation to my advisor, Dr. Olivia Carter-Pokras, for her valuable comments, remarks, and engagement through the process of this master thesis. You have been a tremendous mentor for me. I would also like to thank Dr. Jie Chen, Dr. Xin He, and Dr. Mei-Ling Ting Lee for serving as my committee members. Thank you for your expertise and contributions, making this an enjoyable process.

Deepest thanks to my family: Mom, Dad, and Mie. Words cannot express how grateful I am to be your daughter and sister. I would especially like to thank my epidemiology and biostatistics classmates and Jeff Pongsiri for your assistance with SAS and your brilliant comments and suggestions on this master thesis as well as for your support throughout the entire graduate school process.

Also, I would like to thank the NIS-Teen dataset managers and participants for helpful dataset contributions, the Federal Semester Program and Dr. Joan Burton for my tuition funding, CIVICUS and Dr. Sue Briggs for igniting my passion for fighting against health disparities, and the McNair Program for introducing me to independent research. Lastly, I also would like to express my appreciation to my National Institutes of Health supervisors and colleagues for their

endless support, encouragement, and flexibility. I have been fortunate to have the opportunity to complete my graduate school while working at one of the most prestigious organizations in the world. 


\section{TABLE OF CONTENTS}

Table of Contents $\quad$ iii

List of Tables

List of Figures $\quad \mathrm{V}$

List of Abbreviations vi

Chapter 1: Introduction 1

ACIP Recommendations for HPV vaccine series Importance of Timing of the HPV vaccine series

Racial/ethnic disparities in HPV vaccination uptake in the United States

Chapter 2: Research Questions and Hypotheses 4

Chapter 3: Background: Review of Literature 6

Factors associated with HPV vaccine uptake in the United States

Efforts to increase HPV Vaccine uptake in the United States

Vaccine for Children Program (VFC)

Immunization Grant Program (Section 317)

Medicaid

Children's Health Insurance Program (CHIP)

Patient Protection and Affordable Care Act

Gaps in the literature

Chapter 4: Methods

11

Study Population

Human Subjects \& Ethical Issues

Dependent Variable

Compliance of age at initiation of the HPV vaccine series

Independent Variables

Race/Ethnicity

Socioeconomic Status

Health Insurance Coverage

Potential Confounders and Effect Modifiers

Healthcare utilization

Previous vaccination history of childhood vaccines

Statistical Analysis

Chapter 5: Results

Chapter 6: Discussion

Summary and implications

Strengths

Limitations

Public Health Significance

Appendices

45

References 


\section{LIST OF TABLES}

Table 1: Weighted Percentages and Numbers of on-time and late initiators among 1317 year-old females who received at least one HPV vaccine shot in the United States, 2011

Table 2: Socio-demographic and health care characteristics of 13-17 year-old females who received at least one HPV vaccine shot in the United States, 2011

Table 3: Univariate analysis of on-time HPV vaccine initiation among 13-17 year-old females who received at least one HPV vaccine shot in the United States, 2011

Table 4A: Stratified analysis of on-time initiation of first HPV vaccine by marital status and race/ethnicity, mother's education, health insurance coverage, and poverty status in the United States, 2011

Table 4B: Stratified analysis of on-time initiation of first HPV vaccine by number of children under 18 in household, race/ethnicity, mother's education, health insurance coverage, and poverty status in the United States, 2011

Table 4C: Stratified analysis of on-time initiation of first HPV vaccine by number of primary care visits in the past 12 months, race/ethnicity, mother's education, health insurance coverage, and poverty status in the United States, 2011

Table 4D: Stratified analysis of on-time initiation of first HPV vaccine by number of Hepatitis B shots, race/ethnicity, mother's education, health insurance coverage, and poverty status in the United States, 2011

Table 5: Multivariate analysis of on-time HPV vaccine initiation among 13-17 year-old 36 females who received at least one HPV vaccine shot in the United States, 2011

Table 6A: Sensitivity analysis for weighted percentages and numbers of on-time and late initiators among 13-17 year-old females who received at least one HPV vaccine shot in the United States, 2011 (excluded $12-13$ age groups)

Table 6B: Sensitivity analysis for multivariate analysis of on-time HPV vaccine initiation among 13-17 year-old females who received at least one HPV vaccine shot in the United States, 2011 (excluded 12 - 13 age groups) 


\section{LIST OF FIGURES}

Figure 1: Factors associated with initiation of the HPV vaccine series

Figure 2: Confounding variable assessment for marital status and exposure

(race/ethnicity) and outcome (on-time initiation of the HPV vaccine series) 


\section{LIST OF ABBREVIATIONS}

ACA

ACIP

AOR

CDC

CHIP

CI

DHHS

FDA

HIM

HPV

NCHS

NCIRD

NIS-Teen

OMB

OR

QALY

VFC
Affordable Care Act

Advisory Committee on Immunization Practices

Adjusted Odds Ratio

Centers for Disease Control and Prevention

Children's Health Insurance Program

Confidence Interval

U.S. Department of Health and Human Services

U.S. Food and Drug Administration

Health insurance module

Human Papillomavirus

National Center for Health Statistics

National Center for Immunizations and Respiratory Diseases

National Immunization Survey - Teen

Office of Management and Budget

Odds Ratio

Quality-adjusted life year

Vaccines for Children Program 


\section{CHAPTER 1: INTRODUCTION}

Human Papillomavirus (HPV) is one of the most common sexually transmitted diseases in the United States (U.S.) and worldwide (1). Approximately 20 million people are currently infected with HPV in the U.S. and about six million more are infected each year (2). About half

of these infections are among 15-24 year-old young adults (2). More than half of sexually active men and women are infected with HPV at some time in their lives (2).

Furthermore, being infected with HPV is the greatest risk factor for cervical cancer (3). According to the World Health Organization (WHO), cervical cancer is the third most common type of cancer among women worldwide (4). Centers for Disease Control and Prevention (CDC) estimates that the U.S. spends more than $\$ 4$ billion in direct health care costs for treatment of HPV-related diseases each year (1). Other studies estimate that the cost per quality-adjusted life year (QALY) gained by HPV vaccination of 12 year-old females ranges from $\$ 3,000$ to $\$ 43,600$ per person $(1,5,6)$. With rising healthcare expenditures in the U.S., using HPV vaccination as a preventive health measure offers our nation an enormous cost-saving opportunity.

\section{Advisory Committee on Immunization Practices (ACIP) Recommendations for HPV vaccination}

The U.S. Food and Drug Administration (FDA) approved two HPV vaccines, "Gardasil" in 2006 and "Cervarix" in 2009, to protect against high-risk HPV types (HPV-6, HPV -11, HPV16, and HPV-18) which caused approximately $70 \%$ of occurrences of cervical cancer in the U.S. $(2,7,8)$. As a result, the CDC's Advisory Committee on Immunization Practices (ACIP) recommended the routine use of HPV vaccination among 9-26 year old females and males. The ACIP recommendation for female use of HPV vaccination was released in 2007 with an additional update in 2010 (9). Recommendations for males did not appear until the end of 2011 
(9). All recommendations were based on series of clinical trials, where HPV vaccines were proven to be safe and effective for these age groups.

The ACIP recommended that the first HPV shot of a three-dose vaccine series be initiated by 11 or 12 years of age $(1,10,11,12)$. Each 0.5 milliliter-dose should be administered over a six-month period: the second dose is to be $1-2$ months after the first dose and the third dose is to be given 6 months after the first dose $(10,11)$. It is highly recommended that children initiate HPV vaccination before they become sexually active and contract HPV infections $(10,11)$. Delaying initiation of the HPV vaccine series decreases protection against the HPV infection and can lead to the development of cervical cancer and serious HPV-related diseases in adulthood (9). Despite these recommendations, CDC estimates that only $30 \%$ of U.S. females received three doses of the HPV vaccine by ages 13-15 in $2011(13,14)$.

HPV vaccination is most effective if initiated prior to exposure to $\operatorname{HPV}$ infection $(10,12)$. Data from the 2003 National Survey of Adolescents and Young Adults suggests that there is low opportunity for HPV exposure at 11 years of age or younger since sexual experience is still very low (52). By the age 14, there is a significant increase in opportunity for HPV infection exposure (52). Therefore, compliance with ACIP recommendations for age at initiation of HPV vaccine series is extremely beneficial.

Research has shown that HPV vaccine does not treat infection for people who have already been infected with HPV (72). Although some people may already have acquired one or more type of HPV infection, HPV vaccine could still protect them from other types of HPV infection $(2,7,8,72)$. 


\section{Importance of Timing of the HPV vaccine series}

Timing of initiation of the HPV vaccine series may be more essential than completing all three HPV vaccine doses, according to previous randomized controlled studies $(69,70)$. Study findings confirmed that earlier initiation of HPV vaccination for females were more effective compared to later initiation of HPV vaccination (68). Furthermore, they found that females who received two doses of HPV vaccination gained a similar protective effect as those who received three doses $(68,69,70)$. The risk for HPV infection decreased tremendously after receiving only two doses of HPV vaccination $(69,70)$. Compared to females with no vaccination, females who received two doses of HPV vaccination had $0.29(95 \% \mathrm{CI}, 0.21,0.40)$ odds for the HPV infection risk, whereas females who received all three doses of HPV vaccination had 0.18 (96\% CI: $0.15,0.22$ ) odds for the HPV infection risk (69).

\section{Racial/ethnic disparities in the HPV vaccine series initiation in the United States}

In the U.S., the number of cervical cancer cases and deaths significantly decreased over the past several years (15). This decrease is thought to be due to the success of public health preventions and wide-scale implementation of Pap smear screenings (15). Despite this reduction, non-Hispanic Blacks and Hispanics are less likely than non-Hispanic Whites to initiate the HPV vaccination series $(18,19,20,21)$.

Disparities in the utilization of preventive services exist between whites and racial/ethnic minorities $(75,76,77)$. Compared to Whites, Hispanics, Asians, and Blacks are less likely to use preventive services, including cervical cancer screening $(75,76,77)$. Additionally, racial/ethnic minorities are less likely than whites to have health insurance, as were people with low SES compared to people with high SES (77). 


\section{CHAPTER 2: RESEARCH QUESTIONS AND HYPOTHESES}

The overall goal of this thesis was to assess compliance with ACIP recommendation regarding age at initiation of the HPV vaccine series, and identify related socioeconomic status (SES), racial/ethnic, and health insurance coverage factors. This study aimed to:

1) Compare age at initiation of HPV vaccine series with ACIP recommendations among 1317 year-old females who received at least one dose of the HPV vaccine series.

2) Examine variations in compliance with ACIP recommendations for age at initiation of the HPV vaccine series by SES, race/ethnicity, and health insurance coverage. The association was assessed by the following questions:

a. Was initiating the HPV vaccine series at the ACIP-recommended age associated with SES?

$\mathrm{H}_{0}$ : SES was not associated with timely initiation of the HPV vaccine series. People with higher SES were as likely to report having received their first HPV shot on-time as people with lower SES.

$\mathrm{H}_{1}$ : SES was associated with timely initiation of the HPV vaccine series. People with higher SES were more likely to report having received their first HPV shot on-time compared to people with lower SES.

b. Was initiating the HPV vaccine series at the ACIP-recommended age associated with race/ethnicity?

$\mathrm{H}_{0}$ : Race/ethnicity was not associated with timely initiation of the HPV vaccine series. Racial/ethnic minorities were as likely to report having received their first HPV shot on-time as non-Hispanic Whites.

$\mathrm{H}_{1}$ : Race/ethnicity was associated with timely initiation of the HPV vaccine series. Racial/ethnic minorities were less likely to report having received their first HPV shot on-time compared to non-Hispanic Whites. 
c. Was initiating the HPV vaccine series at the ACIP-recommended age associated with having health insurance coverage?

$\mathrm{H}_{0}$ : Having health insurance coverage was not associated with timely initiation of the HPV vaccine series.

$\mathrm{H}_{1}$ : Having health insurance coverage was associated with timely initiation of the HPV vaccine series.

The study population for the 2011 NIS-Teen survey was 13 - 17 year-old children at the time of the interview in 2011. Since the ACIP recommendation for male use of the HPV vaccine did not appear until the end of 2011, we excluded all males as well as any out of range ages from the analysis. This study's inclusion and exclusion criteria, data source, and sample size ( $\mathrm{n}=$ $5,965)$ are discussed in more detail in the methods section. 
CHAPTER 3: BACKGROUND: REVIEW OF LITERATURE

\section{Factors associated with HPV vaccine uptake in the United States}

In addition to race/ethnicity and SES, infrequent healthcare visits and lack of health insurance coverage have been frequently cited as barriers to receiving timely vaccinations (16, $17,20,22,24,54,66)$. The HPV vaccine is one of the most expensive vaccines with an estimated cost of $\$ 390$ total (\$130 per dose) to administer three HPV vaccine shots over a sixmonth period $(54,66)$. In the U.S., private health insurance covered the cost of vaccinations for many individuals. Public health insurance, such as Medicaid and the Vaccines for Children Program (VFC), covered vaccinations for low-income individuals (54). Individuals without health insurance coverage were the most likely to face the high cost of vaccination. This may be their greatest barrier to receiving HPV vaccination (54). The implementation of the Patient Protection and Affordable Care Act (ACA) is expected to decrease the number of uninsured individuals and consequently lead to an increase in HPV vaccine uptake (25).

A systematic review of 25 published peer-reviewed studies on "factors associated with HPV vaccine uptake in teenage girls" found that higher HPV vaccine series initiation was associated with socioeconomic status, race/ethnicity, and health insurance coverage (20). Having some type of health insurance coverage, whether private or public, was associated with higher HPV vaccine series rates compared to not having health insurance coverage. Interestingly, the HPV vaccine series initiation rate was highest among people with public health insurance, compared to those with private health insurance. Other factors associated with HPV vaccine uptake included age, vaccination history of other childhood vaccines, and healthcare utilization (20). 
In 2013, Fisher supported some of Kessels' findings with a more comprehensive systematic review and meta-analysis of the literature regarding racial/ethnic and SES differences in HPV vaccine uptake (21). Incorporating more recent published articles, Fisher's updated review strengthened some of Kessels' findings on disparities in HPV vaccine initiation experienced by racial/ethnic minorities and people without health insurance coverage (21). Interestingly, Fisher did not find a significant association for HPV vaccine initiation and mother's education and income (21).

\section{National pattern for HPV vaccine and other childhood vaccines in the U.S.}

In general, the same patterns are found for uptake of childhood vaccines with the exception of HPV (74). In the U.S., vaccination coverage was comparable for Tdap, MenACWY, MMR, hepatitis B, and varicella across poverty levels and racial/ethnic groups. Coverage for all of these vaccines was lower for those with low SES as well as those who are racial/ethnic minorities (74). However, HPV vaccination coverage did not follow this pattern. Higher HPV vaccination coverage was observed for people living below poverty level (74). Both Hispanic males and females had higher initiation rates for HPV vaccine while HPV vaccine series completion was lower among Hispanics and blacks, compared to whites (74).

\section{Efforts to increase HPV vaccine uptake in the United States}

Public programs exist to offer assistance to individuals who do not have health insurance, based on specific eligibility criteria. These programs include the Vaccines for Children Program (VFC), Immunization Grant Program (Section 317), Medicaid, Children's Health Insurance Program (CHIP), and Patient Protection and Affordable Care Act (ACA) (26, 27, 28, 29).

Vaccines for Children Program (VFC). This program covers vaccines recommended by the ACIP, including children younger than 19 years old who do not have health insurance and 
those who are categorized as "underinsured" $(27,30,31,32)$. Underinsured children are defined as children who have private health insurance that does not cover vaccination $(27,31,32)$. Free vaccines are also offered to children who are Medicaid-eligible and have American Indian or Alaskan Native background $(27,31,32)$. Because the VFC Program supplies vaccines to all states, it has increased vaccine uptake among eligible children younger than 19 years old while lowering vaccine prices for all states (30).

Immunization Grant Program (Section 317). Federal grants are distributed to state and local government public health agencies to subsidize vaccine costs and to help cover children younger than 19 years old who are not eligible for the VFC program (28). This program attempts to close the gap for children who were not covered under VFC, but require assistance paying for vaccines.

Medicaid. Medicaid covers HPV vaccination for 19-20 year-old adolescents who are eligible to receive Medicaid (27).

Children's Health Insurance Program (CHIP). This program provides health insurance coverage to approximately 8 million children whose families do not qualify for Medicaid but are not able to afford private health insurance (33).

Patient Protection and Affordable Care Act of 2010 (ACA). ACA requires most health insurance plans to provide $100 \%$ coverage for HPV vaccines without any cost-sharing to any enrollees starting September 23, $2010(27,34,35)$. This means that most private health insurance plans are mandated to cover HPV vaccine with no co-pay or deductibles after the implementation of the ACA $(27,34,35,73)$. Newly eligible people for Medicaid in states that chose to expand coverage are also covered for the HPV vaccine series without any cost-sharing expenses (27). Other significant reforms, such as individual mandate, health insurance exchange, and 
prohibition to deny coverage due to pre-existing conditions, took effect starting January 1, 2014 $(27,34,35,73)$. The implementation of the ACA narrows the gaps in HPV vaccination funding and is expected to increase access to preventive services including access to the HPV vaccine in the U.S. While the ACA requires that most U.S. citizens and legal residents have health insurance coverage or pay penalty fees, some people are still left out of the health insurance system (37). People who are not required to have health insurance coverage include those who are a part of any religion opposing a health insurance plan, undocumented immigrants, in prison, a member of any Indian tribe, have family income below the tax return filing threshold, and paying more than $8 \%$ of total income for a health insurance plan (37). It is estimated that full implementation of the ACA still leaves about 23 million people without health insurance $(38,39$, 61, 71). Access still remains one of the most difficult challenges for these subgroups of the U.S. population $(38,39,71)$.

Furthermore, having health insurance coverage did not necessarily mean one has access to healthcare (71). According to Penchansky and Thomas, access to healthcare includes availability, accessibility, accommodation, affordability, and acceptability (40). Health insurance coverage only contributes to a portion of an individual's overall health and well-being (71). Having health insurance coverage does not necessarily determine ultimate health outcomes (71).

\section{Gaps in the literature}

Numerous studies, such as those discussed in Kessels' and Fisher's systematic reviews, have examined factors associated with initiation of the HPV vaccination series, but little is known about factors associated with timely HPV vaccine uptake $(20,21)$. This study focuses on the importance of compliance with ACIP recommendation regarding age of initiation or on-time vaccination initiation. 
This study builds on prior research studies examining factors associated with initiation of HPV vaccine. New knowledge from this study could equip us with better knowledge on timely initiation of HPV vaccine series. Population-targeted interventions could be developed to address disparities in timely HPV vaccination initiation in the U.S. 


\section{CHAPTER 4: METHODS}

The National Immunization Survey -Teen (NIS-Teen) was used to conduct this crosssectional study (2011). The 2011 NIS-Teen was conducted jointly by the National Center for Immunizations and Respiratory Diseases (NCIRD) and the National Center for Health Statistics (NCHS) (41).

The 2011 NIS -Teen Survey collected data from both households and vaccination providers (42). The first part of the two-phase survey was the random-digit-dialing telephone survey with randomly selected households in all 50 states and the District of Columbia (42). Participant's consent was obtained from parents or guardians of eligible children in order to contact their vaccination providers. The second phase of the survey was to perform a record check with the vaccination providers through mail survey questionnaire (42). The purpose of sending the mail surveys to the vaccination providers was to collect children's immunization data from their medical records and to assure the accuracy and precision of overall vaccination coverage estimates (42).

In order to reduce measurement error, the 2011 NIS-Teen staff collected the children's date of birth instead of directly asking for the age of the children during the first phase of the study (42). Various methods were used to minimize bias. Computer-assisted telephone interviewing (CATI) software was used to calculate children's age and determine their eligibility (42). The 2011 NIS-Teen also collected dates of vaccine shots from the second phase of the study. Vaccination dates were used with the children's dates of birth to calculate the age of children in years at the reported vaccination dates (42). 


\section{Study Population}

The study population for the 2011 NIS-Teen was 13-17 year-old children at the time of the interview in the 2011 calendar year (42). Children ages 13-17 years during the 2011 data collection were required to have their birth year between 1993 and 1999 in order to be included in the survey study (42). The 2011 NIS-Teen was conducted in conjunction with the 2011 NIS. While the 2011 NIS obtained vaccination coverage rates among children who were between 19 and 35 months old for vaccinations, such as DTtaP, polio, measles, Flu, and other required childhood vaccinations, the 2011 NIS - Teen obtained vaccination coverage rates for older children (41). The 2011 NIS-Teen identified households containing one or more children who were 13-17 years of age (41). Interviews were conducted with household adults who were most knowledgeable about the children's vaccination records (41). After the completion of the household portion, the 2011 NIS-Teen also contacted the children's vaccination providers to request information on vaccinations from the children's medical records (41). The 2011 NISTeen response rate for the telephone household survey was $57.2 \%$, and the percentage of children with adequate provider data was $61.5 \%(42)$.

The criteria for inclusion in this research study were $(n=5,965)$ :
A. Being female,
B. Between 13-17 years of age by the time of the interview in 2011,
C. At least one HPV shot was received, and
D. The first HPV shot was received between 9 -17 years of age.

Although the HPV vaccine series had been approved for 9-26 year-old children and adults, the 2011 NIS-Teen only collected data for those 13-17 years of age. Therefore, our study 
was limited to those females who received at least one HPV shot and the first HPV shot was received between the ages of $9-17$.

ACIP recommends that the HPV vaccination series can be started beginning at 9 years of age, but has not issued a recommendation for children younger than 9 years of age $(7,8,43,44)$. Therefore, children who reported having received at least one shot of the HPV vaccine series when they were less than 9 years of age were excluded from our study. The 2011 NIS - Teen staff completed data collection around the time that the ACIP released their recommendation for males in December $2011(10,11,12)$. Because the ACIP recommendation for males was released after 2011 NIS-Teen data collection occurred, males were excluded from our study. The final sample size for this study is 5,965 .

\section{Human Subjects \& Ethical Issues}

The 2011 NIS public-use data file was used for this secondary data analysis study. The 2011 NIS - Teen staff have taken various steps to ensure that participants' sensitive information and confidentiality were protected from the beginning to the end of the survey (42). The 2011 NIS-Teen staff also received prior human subjects' approval from the Office of Management and Budget before starting their survey study (42).

During the data collection phase, the 2011 NIS-Teen staff sent advance notification letters, provided an overview of the study, and obtained informed oral consent from the participants. These steps were taken in order to protect participants' confidentiality and ensure them that their participation was entirely voluntary (42). Once participants were identified as having the most knowledge in the household in regards to the eligible children's vaccine history, they were asked for informed consent to participate in the 2011 NIS-Teen (42). At the end of the 
interview, the 2011 NIS-Teen interviewers asked the participants for permission to contact the children's vaccination providers (42).

Before the 2011 NIS - Teen public-use data files can be published on the CDC's website, they had to go through an extensive process to protect participants' privacy and data confidentiality (42). In accordance with the NCHS's established standards for the release of all NCHS survey data, the 2011 NIS-Teen public-use data files were required to undergo a comprehensive review by the NCHS Disclosure Review Board (42). The 2011 NIS -Teen public-use data file webpage clearly indicates that the dataset can be used only for research purposes. Any violators of the privacy and confidentiality of the participants can be punished by law $(45,46)$.

In December of 2013, the University of Maryland Institutional Review Board (IRB) reviewed this thesis' "Human Subject Determination" Form and declared it "exempt." Since the 2011 NIS-Teen data was available to the public, the UMD IRB determined that this thesis meets at least one of the federal exempt categories criteria. Therefore, there is no requirement for annual review or expiration date listed on the final approval letter.

\section{Dependent Variable}

The outcome of interest was compliance regarding age at initiation of the HPV vaccine series. Based on the ACIP recommendation, those who received the first dose of HPV vaccination at or before 12 years of age were considered "on-time" initiators. Those who received the first dose of HPV vaccination after the age of 12 were considered "late" initiators.

Based on the preliminary analyses of the dependent variables of this dataset, providerreported data were more complete than household-reported data. Provider data $(\mathrm{n}=7470)$, which included all children who received at least one HPV vaccine shot in 2011 NIS-Teen, had a 
considerably larger sample size, compared to the provider data $(\mathrm{n}=2172)$. Therefore, the provider-reported data from the 2011 NIS-Teen Survey were used for the data analysis (42). Independent Variables

Race/Ethnicity. Race/ethnicity information was collected in the 2011 NIS-Teen with multiple categories. In compliance with the Office of Management and Budget's (OMB) standards for federal statistics reporting and the classification of race/ethnicity in the United States, the 2011 NIS Teen collected data on race/ethnicity groups as follows: Hispanic, NonHispanic White Only, Non-Hispanic Black Only, Alaska Native, Asian, Native Hawaiian/Pacific Islander, Other, Do not know, and Refused. The 2011 NIS - Teen had recoded race/ethnicity variables and categorized into Hispanic, Non-Hispanic White Only, Non-Hispanic Black Only, and Non-Hispanic Other and Multi-Racial $(16,42,47)$.

Socioeconomic Status. SES was determined by using the children's "mother's educational level" and "poverty status." Mother's education was sorted into four categories: college graduate, greater than 12 years but not completed college, 12 years, and less than 12 years.

Poverty status took into account the household income and number of people in the household. Based on the 2009 Census poverty thresholds, the 2011 NIS-Teen divided the poverty status into three categories (42). The categories were: 1) Those who are living at or above the federal poverty level and having a household income greater than $\$ 75,000$ (Above poverty level, $>\& 75 \mathrm{~K}), 2$ ) Those living at or above the federal poverty level and having a household income less than or equal to $\$ 75,000$ (Above poverty level $\leq \$ 75 \mathrm{~K}$ ), and 3 ) Those living below the federal poverty level (Below poverty level) (42). 
Health insurance coverage. Information on health insurance coverage was gathered from the Health Insurance Module (HIM) in the NIS-Teen Survey. Response categories were included in the 2011 NIS-Teen survey as follows:
a. Through employer or union (Private)
b. Medicaid (Public)
c. Child Health Insurance Plan-CHIP (Public)
d. Medicaid or CHIP (Public)
e. Indian Health Service (Other)
f. Military Health Care, Tricare, Champus, or Champ-VA (Other)
g. Other Health Insurance (Other)
h. Uninsured (No insurance)

Based on previous studies using NIS-Teen datasets to examine health insurance coverage variables and Census Bureau's definitions of health insurance $(16,48,56,57)$, I re-categorized the health insurance coverage information as follows: Private, Public, Other, and None.

\section{Potential Confounders and Effect Modifiers}

From the existing literature, potential confounders for initiating HPV vaccine were family composition, previous vaccination history of other childhood vaccines, parent's HPV vaccinerelated beliefs, attitudes, and intentions, having HPV-related knowledge, healthcare utilization, and having a healthcare provider as a source of information $(20,21)$. In this thesis, only potential confounding variables that were available in the NIS-Teen dataset were tested and controlled during the statistical analysis. These variables also met criteria for confounding (associated with both the exposure and the outcome while not a part of the causal pathway). From Figure 1, these variables include family composition (marital status, number of children in household under age 18), healthcare utilization (number of primary care visits in past 12 months), and previous vaccination history of childhood vaccines (number of hepatitis B vaccine shot). 
Figure 1: Factors associated with initiation of the HPV vaccine series

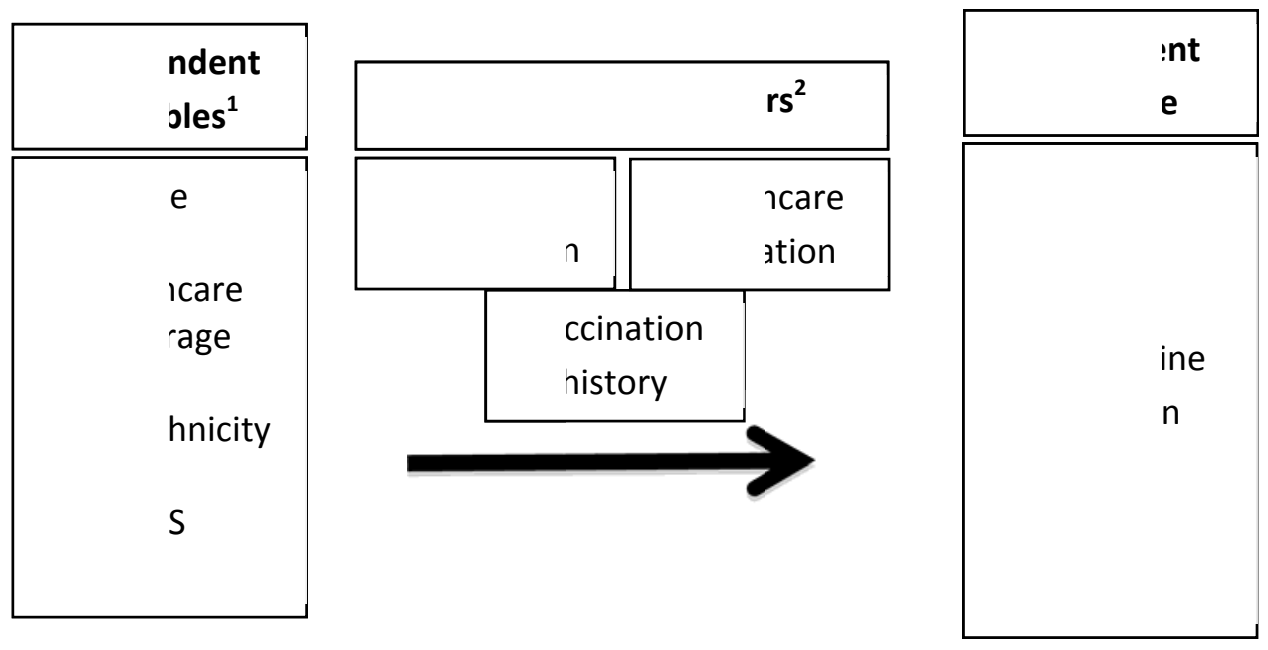

${ }^{1}$ Factors associated with initiation of HPV vaccine based on previous literature, and independent variables of interest in this study

${ }^{2}$ Factors associated with initiation of HPV vaccine based on previous literature, and potential confounders in this study

Source: $(20,21)$

Family composition. Family composition was examined using "Mother's Marital Status" and "Number of children in household under age 18." Mother's marital status was categorized into: Single and Married. In this study, the "single" category included all those who were widowed, divorced, separated, and never married as well as those whose husbands had deceased. Number of children in household was categorized into: 1, 2-3, and 4 or more.

Healthcare utilization. Healthcare utilization was also a potential confounder. Use or access to healthcare was the variable used for healthcare utilization. It was determined through the question "During the past 12 months, how many times has [Teen] seen a doctor or other healthcare professional about [his/her] health at a doctor's office, a clinic, or some other places?" (42.) The number of primary care visits was categorized into: $0,1,2-3,4-5$, and 6 or more.

Previous vaccination history of childhood vaccines. "Previous vaccination history of other childhood vaccines" variable was examined using the number of Hepatitis B vaccine shots reported in the 2011 NIS-Teen. Although information on several childhood vaccines (Hepatitis 
A, Hepatitis B, Tdap, Meningococcal, MMR, Varicella zoster, Influenza) was available through the 2011 NIS-Teen, Hepatitis B vaccination history was chosen and used as a proxy for "previous vaccination history of childhood vaccines" $(20,21)$. Several peer-reviewed studies have found that vaccination history of hepatitis B to be the strongest predictor of HPV vaccine series initiation among females $(49,55)$. Hepatitis B vaccine protects against Hepatitis B viral infection, which is another type of sexually transmitted infection (STI) (50). Hepatitis B infection is prevalent among sexually active individuals and those who use drug needles (78). However, the source of infection is still unknown for $30 \%$ of those who currently have Hepatitis B infection today (78). Having Hepatitis B infection could lead to serious diseases, such as liver cancer and cirrhosis. Similar to the HPV vaccine's numbers of dosage, Hepatitis B vaccine is given in a three-dose series over a 6-month period (50). The current Hepatitis B vaccination was used since in 1986 and in 2005, ACIP updated to its recommendation to include all children and adolescents ages $<19$ years $(50,78)$. "Number of Hepatitis B vaccine" in this study was categorized into: $0,1-2,3$, and 4 or more.

\section{Statistical Analysis}

For this thesis, the CDC public data file was downloaded and SAS version 9.3 was used. In the preliminary analyses, frequency distributions and univariate analyses were conducted to examine associations between on-time initiation of the first HPV shot and mother's education, poverty level, race/ethnicity, and health insurance coverage. Descriptive statistics were used to provide a quantitative description of the study sample and examine the distribution of independent variables, dependent variables, and covariates. SES, race/ethnicity, health insurance coverage and other socio-demographic variables are presented in Table 1. 
Data were analyzed using SAS 9.3 survey procedures, and applying appropriate sampling weights because of the complex survey design. PROC SURVEYFREQ was used to examine the relationships between all variables and on-time vaccination. The Rao-Scott Chi-Square $\left(\chi^{2}\right)$ Test was performed to examine significant differences between those who have initiated the HPV vaccine series "on-time" and those who initiated it "late." Unadjusted logistic regression models were run for these variables separately. Then, multivariate logistic regression analysis was conducted to examine effects of independent variables on on-time initiation of HPV vaccine series while controlling for confounders. Adjusted odds ratios and 95\% confidence intervals were calculated.

Additionally, the complex sampling design was accounted for and addressed in the statistical analysis, as recommended in the 2011 NIS-Teen Data User's Guide (42). The 2011 NIS-Teen had already made an adjustment to the weights in order to account for differences among various groups. According to the 2011 NIS-Teen Data User's Guide, children who had access to regular healthcare services were more likely to be captured in the provider data, compared to those who did not have regular healthcare services $(42,51)$. This group traditionally came from a wealthier population and had been over-represented in the provider data; therefore weights were developed and adjusted by the 2011 NIS-Teen in order to achieve an accurate representation of the survey's target population. The weight variable "PROVWT_D" was therefore used to adjust for the dual sample frame of landline and cell phones, and take into account these differences in the population (42).

To evaluate confounding and effect modifications, stratified analyses were performed for all potential confounders using PROC SURVEYLOGISTIC in SAS version 9.3. These variables included family composition (marital status, number of children in household under age 18), 
healthcare utilization (number of primary care visits in past 12 months), and previous vaccination history of childhood vaccines (number of hepatitis B vaccine shots). Additional criteria for assessing confounders used to test potential confounders included: 1) Confounding variable was associated with the exposure, 2) Confounding variable was associated with the outcome, and 3) Confounding variable was not part of the causal pathway between the exposure and the outcome. For example, one of the variables representing family composition was "mother's marital status." Mother's marital status was categorized into: single or married. For example, mother's marital status was stratified by race/ethnicity, poverty level, mother's education, and health insurance coverage. To examine variables for confounding, the crude ORs was compared with the adjusted ORs. If the adjusted ORs were at least $10 \%$ different from the crude ORs, we determined the variable as a confounder. To examine variables for effect modification, we looked at the stratified ORs in the subgroup and determined if they are different from one another.

To evaluate for multicollinearity, PROC REG and Variance Inflation Factor (VIF) were used in SAS 9.3. As the degree of VIF increases, the estimates from the logistic regression model become unstable. The result from the multicollinearity test indicated that none of our variables have VIF values greater than 10 (Appendix D). Therefore, multicollinearity is not a problem in this study.

Lastly, sensitivity analyses were performed using the same SAS procedures but without 12 and 13 age groups. Since the majority of the study sample received the first HPV shot at the ages of 12 and 13 (age $12=1,598$ and age $13=1,321$ ), we took out these age groups and ran the same procedures. We redefined those who received the first HPV shot between ages 9-11 yearolds as "on-time" and ages 14-17 year-olds as "late." The results of the sensitivity analyses were compared to the original results for comparison. 
CHAPTER 5: RESULTS

\section{Descriptive statistics: Socio-demographic characteristics and distribution of age at initiation of HPV vaccines series}

Among 13-17 year old females who had received at least one HPV vaccine shot during $2011(n=5,965), 47.7 \%$ reported having received the first shot between 9-12 years of age or ontime (Table 1).

Table 2 presents socio-demographic and health care characteristics for 13-17 year old females who had received at least one HPV vaccine shot in 2011. On-time initiation ranged from $49 \%$ for non-Hispanic Whites to $55 \%$ for Hispanics. Females who lived in households with more children were more likely to initiate their HPV vaccine series on-time. In addition, females who lived in households with higher incomes, and higher maternal education were less likely to initiate their HPV vaccine series on-time compared to females in lower socioeconomic status households. For example, $46.8 \%$ of females who lived in a household with an income over $\$ 75,000$ had received their first HPV shot on-time compared to $54.3 \%$ of females living below the federal poverty level. Similarly, females with private health insurance coverage $(32.4 \%)$ were the least likely to start their HPV vaccine series on-time than any other insurance group, including those without health insurance (43.7\%). Females who had not received a Hepatitis B vaccine shot were also less likely to initiate their HPV vaccine series on-time (35.7\%) compared to females who had received one or more Hepatitis B shots ( $45.5 \%$ to $56.7 \%)$. 
Table 1: Weighted Percentages and Numbers of on-time and late initiators among 13-17 year-old females who received at least one HPV vaccine shot in the United States, 2011

\begin{tabular}{|c|c|c|c|}
\hline $\begin{array}{l}\text { Age in years at time of } \\
\text { first HPV vaccine shot }\end{array}$ & $\begin{array}{l}\text { Number } \\
\text { in sample }\end{array}$ & $\begin{array}{l}{ }^{3} \text { Weighted } \\
\text { Frequency }\end{array}$ & $\begin{array}{l}{ }^{3} \text { Weighted } \\
\text { Percent }\end{array}$ \\
\hline \multicolumn{4}{|l|}{${ }^{1}$ On-time } \\
\hline 9 & 56 & 71911 & $1.3 \%$ \\
\hline 10 & 193 & 179472 & $3.3 \%$ \\
\hline 11 & 1145 & 1002414 & $18.2 \%$ \\
\hline 12 & 1598 & 1377741 & $24.9 \%$ \\
\hline Total & 2992 & 2631538 & $47.7 \%$ \\
\hline \multicolumn{4}{|l|}{${ }^{2}$ Late } \\
\hline 13 & 1321 & 1283229 & $23.3 \%$ \\
\hline 14 & 914 & 860268 & $15.6 \%$ \\
\hline 15 & 442 & 417087 & $7.6 \%$ \\
\hline 16 & 216 & 257253 & $4.7 \%$ \\
\hline 17 & 80 & 68561 & $1.2 \%$ \\
\hline Total & 2973 & 2886398 & $52.3 \%$ \\
\hline Total & 5965 & 5517935 & $100 \%$ \\
\hline
\end{tabular}

${ }^{1}$ Compliance of age at initiation of the HPV vaccine, defined as "on-time" vaccination based on the ACIP recommendation that the first of the three-dose HPV vaccine be given to girls by the ages of 11 or 12 years old. Children who received the first dose of HPV vaccination before or at the age of 12 are considered "on-time."

${ }^{2}$ Children who received the first dose of HPV vaccination after the age of 12 are considered "late."

${ }^{3}$ Weight was used to adjust for the dual sample frame of landline and cellphone and take into account these differences in the population. 
Table 2: Socio-demographic and health care characteristics of 13-17 year-old females who received at least one HPV vaccine shot in the United States, 2011

\begin{tabular}{|c|c|c|c|c|c|c|c|c|c|c|c|}
\hline \multirow[t]{2}{*}{ Variables } & \multicolumn{4}{|c|}{$\begin{array}{l}\text { On-time Initiators } \\
(n=2,992)\end{array}$} & \multicolumn{4}{|c|}{$\begin{array}{l}\text { Late Initiators } \\
\qquad(n=2,973)\end{array}$} & \multicolumn{3}{|c|}{$\begin{array}{l}\text { Total Initiators } \\
\qquad(n=5,965)\end{array}$} \\
\hline & $\begin{array}{c}\text { Number } \\
\text { in } \\
\text { sample }\end{array}$ & $\begin{array}{c}\text { Unweighted } \\
\%\end{array}$ & $\begin{array}{c}\text { *Weighted } \\
\%\end{array}$ & $+p$-value & $\begin{array}{l}\text { Number } \\
\text { in } \\
\text { sample }\end{array}$ & $\begin{array}{c}\text { Unweighted } \\
\%\end{array}$ & $\begin{array}{c}\text { *Weighted } \\
\%\end{array}$ & t p-value & $\begin{array}{c}\text { Number } \\
\text { in } \\
\text { sample }\end{array}$ & $\begin{array}{c}\% \\
\text { On- } \\
\text { time }\end{array}$ & tp-value \\
\hline $\begin{array}{r}\text { Race/Ethnicity } \\
\text { Hispanic } \\
\text { Non-Hispanic White } \\
\text { Non-Hispanic Black } \\
\text { Non-Hispanic Other and Multi-Racial }\end{array}$ & $\begin{array}{l}546 \\
1856 \\
321 \\
269\end{array}$ & $\begin{array}{l}18.6 \% \\
61.2 \% \\
11.2 \% \\
9 \%\end{array}$ & $\begin{array}{l}26.2 \% \\
50.9 \% \\
15.6 \% \\
7.4 \%\end{array}$ & $<.0001$ & $\begin{array}{l}441 \\
1932 \\
318 \\
282\end{array}$ & $\begin{array}{l}15 \% \\
64.3 \% \\
11.2 \% \\
9.5 \%\end{array}$ & $\begin{array}{l}25.4 \% \\
49.9 \% \\
15.7 \% \\
8.9 \%\end{array}$ & $<.0001$ & $\begin{array}{l}987 \\
3788 \\
639 \\
551\end{array}$ & $\begin{array}{l}55.6 \% \\
49 \% \\
50.2 \% \\
48.8 \% \\
\end{array}$ & $<.0001$ \\
\hline $\begin{array}{lr}\text { Mother's marital status } & \\
& { }^{*} \text { Single } \\
\text { Married }\end{array}$ & $\begin{array}{l}848 \\
2144\end{array}$ & $\begin{array}{l}28.3 \% \\
71.7 \%\end{array}$ & $\begin{array}{l}36.4 \% \\
63.7 \%\end{array}$ & $<.0001$ & $\begin{array}{l}828 \\
2145\end{array}$ & $\begin{array}{l}27.9 \% \\
72.1 \%\end{array}$ & $\begin{array}{l}37.18 \% \\
62.8 \%\end{array}$ & $<.0001$ & $\begin{array}{l}1676 \\
4289\end{array}$ & $\begin{array}{l}50.6 \% \\
49.9 \%\end{array}$ & $<.0001$ \\
\hline $\begin{array}{l}\text { Number of children in the household } \\
\text { under age } 18 \\
\qquad \begin{array}{r}1 \\
2-3 \\
>=4\end{array}\end{array}$ & $\begin{array}{l}1020 \\
1649 \\
323\end{array}$ & $\begin{array}{l}33.9 \% \\
55.2 \% \\
10.9 \%\end{array}$ & $\begin{array}{l}27.1 \% \\
58.3 \% \\
14.7 \%\end{array}$ & $<.0001$ & $\begin{array}{l}1333 \\
1400 \\
240\end{array}$ & $\begin{array}{l}44.6 \% \\
47.4 \% \\
8 \%\end{array}$ & $\begin{array}{l}33.6 \% \\
53.3 \% \\
13.1 \%\end{array}$ & $<.0001$ & $\begin{array}{l}2353 \\
3049 \\
563\end{array}$ & $\begin{array}{l}43.3 \% \\
54.1 \% \\
57.4 \%\end{array}$ & $<.0001$ \\
\hline $\begin{array}{r}\text { Poverty status } \\
\text { Above poverty level }>\$ 75 \mathrm{~K} \\
\text { Above poverty level } \leq \$ 75 \mathrm{~K} \\
\text { Below poverty level }\end{array}$ & $\begin{array}{l}1219 \\
1087 \\
578\end{array}$ & $\begin{array}{l}40.5 \% \\
36.4 \% \\
19.5 \%\end{array}$ & $\begin{array}{l}30.1 \% \\
35.4 \% \\
29.8 \%\end{array}$ & $<.0001$ & $\begin{array}{l}1384 \\
998 \\
487\end{array}$ & $\begin{array}{l}45.9 \% \\
34.2 \% \\
16.2 \%\end{array}$ & $\begin{array}{l}32.7 \% \\
38.6 \% \\
24.3 \%\end{array}$ & $<.0001$ & $\begin{array}{l}2603 \\
2085 \\
1065\end{array}$ & $\begin{array}{l}46.8 \% \\
52.1 \% \\
54.3 \%\end{array}$ & $<.0001$ \\
\hline $\begin{array}{r}\text { Mother's education } \\
\qquad 12 \text { years } \\
12 \text { years } \\
>12 \text { years, non-college graduate } \\
\text { College graduate }\end{array}$ & $\begin{array}{l}373 \\
592 \\
851 \\
1176\end{array}$ & $\begin{array}{l}12.6 \% \\
20.1 \% \\
28.4 \% \\
39 \%\end{array}$ & $\begin{array}{l}19.3 \% \\
24.4 \% \\
27.8 \% \\
28.5 \%\end{array}$ & 0.0003 & $\begin{array}{l}304 \\
556 \\
766 \\
1347\end{array}$ & $\begin{array}{l}10.2 \% \\
18.8 \% \\
25.9 \% \\
45.1 \%\end{array}$ & $\begin{array}{l}15.1 \% \\
25 \% \\
26.2 \% \\
33.7 \%\end{array}$ & $<.0001$ & $\begin{array}{l}677 \\
1148 \\
1617 \\
2523\end{array}$ & $\begin{array}{l}55.1 \% \\
51.6 \% \\
52.6 \% \\
46.6 \%\end{array}$ & $<.0001$ \\
\hline Health Insurance Coverage & $\begin{array}{l}1076 \\
1076 \\
80 \\
185 \\
\end{array}$ & $\begin{array}{l}54.8 \% \\
35.8 \% \\
3 \% \\
6.3 \% \\
\end{array}$ & $\begin{array}{l}43 \% \\
48.1 \% \\
1.9 \% \\
6.8 \% \\
\end{array}$ & $<.0001$ & $\begin{array}{l}1701 \\
884 \\
96 \\
238 \\
\end{array}$ & $\begin{array}{l}58.4 \% \\
29.6 \% \\
3.4 \% \\
8.4 \% \\
\end{array}$ & $\begin{array}{l}46.9 \% \\
39.6 \% \\
2.9 \% \\
10.3 \% \\
\end{array}$ & $<.0001$ & $\begin{array}{l}3316 \\
1960 \\
176 \\
423 \\
\end{array}$ & $\begin{array}{l}32.4 \% \\
54.9 \% \\
45.5 \% \\
43.7 \% \\
\end{array}$ & $<.0001$ \\
\hline
\end{tabular}




\begin{tabular}{|c|c|c|c|c|c|c|c|c|c|c|c|}
\hline \multirow[t]{2}{*}{ Variables } & \multicolumn{4}{|c|}{$\begin{array}{l}\text { On-time Initiators } \\
(n=2,992)\end{array}$} & \multicolumn{4}{|c|}{$\begin{array}{l}\text { Late Initiators } \\
\qquad(n=2,973)\end{array}$} & \multicolumn{3}{|c|}{$\begin{array}{c}\text { Total Initiators } \\
(n=5,965)\end{array}$} \\
\hline & $\begin{array}{l}\text { Number } \\
\text { in } \\
\text { sample }\end{array}$ & $\begin{array}{c}\text { Unweighted } \\
\%\end{array}$ & $\begin{array}{c}\text { *Weighted } \\
\%\end{array}$ & $t_{p \text {-value }}$ & $\begin{array}{l}\text { Number } \\
\text { in } \\
\text { sample }\end{array}$ & $\begin{array}{c}\text { Unweighted } \\
\%\end{array}$ & $\begin{array}{c}\text { *Weighted } \\
\%\end{array}$ & tp-value & $\begin{array}{c}\text { Number } \\
\text { in } \\
\text { sample }\end{array}$ & $\begin{array}{c}\% \\
\text { On- } \\
\text { time }\end{array}$ & tp-value \\
\hline 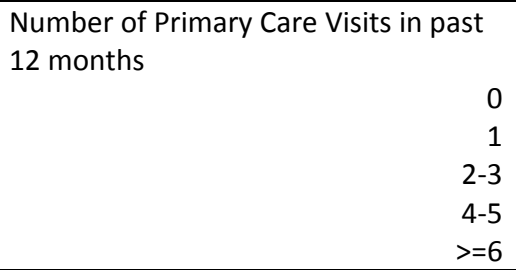 & $\begin{array}{l}392 \\
771 \\
1121 \\
408 \\
288\end{array}$ & $\begin{array}{l}13.5 \% \\
25.9 \% \\
37.2 \% \\
13.2 \% \\
9.5 \%\end{array}$ & $\begin{array}{l}14.6 \% \\
26.4 \% \\
34 \% \\
13.7 \% \\
10 \%\end{array}$ & $<.0001$ & $\begin{array}{l}328 \\
734 \\
1150 \\
412 \\
329\end{array}$ & $\begin{array}{l}11.1 \% \\
24.7 \% \\
38.6 \% \\
13.7 \% \\
11.3 \%\end{array}$ & $\begin{array}{l}13 \% \\
24.3 \% \\
38.4 \% \\
13 \% \\
10.8 \%\end{array}$ & $<.0001$ & $\begin{array}{l}720 \\
1505 \\
2271 \\
810 \\
617\end{array}$ & $\begin{array}{l}54.4 \% \\
51.2 \% \\
49.4 \% \\
50.4 \% \\
46.7 \%\end{array}$ & $<.0001$ \\
\hline $\begin{array}{r}\text { Number of Hepatitis B vaccine shots } \\
0 \\
1-2 \\
3 \\
>=4\end{array}$ & $\begin{array}{l}106 \\
65 \\
2638 \\
183\end{array}$ & $\begin{array}{l}4.3 \% \\
2.6 \% \\
87.1 \% \\
6.1 \%\end{array}$ & $\begin{array}{l}4.8 \% \\
2.3 \% \\
87.2 \% \\
5.7 \%\end{array}$ & $<.0001$ & $\begin{array}{l}191 \\
78 \\
2564 \\
140\end{array}$ & $\begin{array}{l}8.2 \% \\
3 \% \\
84.2 \% \\
4.9 \%\end{array}$ & $\begin{array}{l}7.8 \% \\
2.8 \% \\
85.4 \% \\
4 \%\end{array}$ & $<.0001$ & $\begin{array}{l}297 \\
143 \\
5202 \\
323\end{array}$ & $\begin{array}{l}35.7 \% \\
45.5 \% \\
50.7 \% \\
56.7 \%\end{array}$ & $<.0001$ \\
\hline
\end{tabular}

Weight was used to adjust for the dual sample frame of landline and cellphone and take into account these differences in the population.

** In this study, "single" includes all those who are widowed, divorced, separated, and never married as well as those whose husbands are deceased.

*** Poverty status is based on the 2009 Census poverty thresholds to calculate income-to-poverty ratio.

$\uparrow$ P-value indicates the probability of the observed chi square if there are no true differences between categories. 


\section{Univariate analyses of on-time HPV vaccine series among 13-17 year-old females}

Crude odds ratios (OR) were calculated to describe on-time initiators who have at least one HPV vaccine shot (Table 3 ). Additionally, $95 \%$ confidence intervals $(\mathrm{CI})$ were used to estimate the precision of the OR. A wider CI showed low level of precision or confidence of the OR while a narrower CI showed greater precision of the OR. If the CI did not include 1, the OR was characterized as statistically significant.

In the univariate analysis, several variables were significant predictors of having received on-time first HPV vaccine series (Table 3). Those with public health insurance coverage had 1.826 (95\% CI: $1.274,2.619)$ odds of initiating on-time when compared to those with no health insurance coverage (Table 3). Females also had greater odds of initiating on-time if they received at least three Hepatitis B vaccine shots (3 Hepatitis B vaccine shots: 1.655, 95\% CI: 1.035 , 2.647; 4 or more Hepatitis B vaccine shots: $2.343,95 \%$ CI: $1.258,4.363$ ) (Table 3). Interestingly, females were less likely to initiate on-time if their households were above the poverty level compared to females whose households were below the poverty level (above poverty level $>\$ 75 \mathrm{~K}: 0.746,95 \% \mathrm{CI}: 0.568,0.98)$; above poverty level $\leq \$ 75 \mathrm{~K}: 0.750,95 \% \mathrm{CI}$ : $0.585,0.961)$. Females with mothers who had more than 12 years of education, non-college graduate, had 0.664 (95\% CI: $0.489,0.903)$ odds of having on-time first HPV vaccine shot when compared to those whose mothers had less than 12 years of education (Table 3 ).

Several factors previously found to be associated with HPV initiation in other studies (race/ethnicity, mother's marital status, and private health insurance coverage) were not statistically significant in the analysis (Table 3). Race/ethnicity was not a significant predictor of on-time initiation. Hispanics had 1.011 (95\% CI: $0.781,1.310)$ odds to initiate on-time when compared to non-Hispanic Whites (Table 3). Non-Hispanic Blacks had 0.971 (95\% CI: 0.731, 
1.289) odds of having an on-time first HPV vaccine shot when compared to non-Hispanic Whites (Table 3). Females with married mothers had 1.036 (95\% CI: $0.846,1.270)$ odds to initiate ontime when compared to females with single mothers (Table 3). Although not significant, females with private health insurance coverage had greater odds of being on-time (OR: 1.379, 95\%:

$0.978,1.945)$ when compared to females with no health insurance coverage (Table 3). 
Table 3: Univariate analysis of on-time HPV vaccine initiation among 13-17 year-old females who received at least one HPV vaccine shot in the United States, 2011

\begin{tabular}{|c|c|c|}
\hline Variables & $\begin{array}{l}\text { "Weighed Crude Odds } \\
\text { Ratio (OR) } \\
(95 \% \mathrm{Cl})\end{array}$ & †p-value \\
\hline Race/Ethnicity & & 0.7032 \\
\hline $\begin{array}{r}\text { Hispanic } \\
\text { Non-Hispanic White Only } \\
\text { Non-Hispanic Black Only } \\
\text { Non-Hispanic Other and Multi-Racial }\end{array}$ & $\begin{array}{l}1.011(0.781,1.310) \\
\text { Reference } \\
0.971(0.731,1.289) \\
0.811(0.569,1.156)\end{array}$ & \\
\hline Mother's marital status & & 0.7311 \\
\hline $\begin{array}{r}\text { Single } \\
\text { Married }\end{array}$ & $\begin{array}{l}\text { Reference } \\
1.036(0.846,1.270)\end{array}$ & \\
\hline Number of children in the household under age 18 & & 0.0081 \\
\hline $\begin{array}{r} \\
2-3 \\
>=4\end{array}$ & $\begin{array}{l}0.720(0.508,1.021) \\
0.976(0.696,1.370) \\
\text { Reference }\end{array}$ & \\
\hline Poverty status & & 0.1121 \\
\hline $\begin{array}{r}\text { Above poverty level }>\$ 75 \mathrm{~K} \\
\text { Above poverty level } \leq \$ 75 \mathrm{~K} \\
\text { Below poverty level }\end{array}$ & $\begin{array}{l}0.749(0.575,0.975) \\
0.750(0.585,0.961) \\
\text { Reference }\end{array}$ & \\
\hline Mother's education & & 0.0426 \\
\hline $\begin{array}{r}<12 \text { years } \\
12 \text { years } \\
>12 \text { years, non-college graduate } \\
\text { College graduate }\end{array}$ & $\begin{array}{l}\text { Reference } \\
0.767(0.546,1.076) \\
\mathbf{0 . 6 6 4}(0.489,0.903) \\
0.833(0.606,1.147) \\
\end{array}$ & \\
\hline Health Insurance Coverage & & $<.0001$ \\
\hline $\begin{array}{rr}\text { Private } \\
\text { Public } \\
\text { Other } \\
\text { None }\end{array}$ & $\begin{array}{l}1.379(0.978,1.945) \\
1.826(1.274,2.619) \\
0.986(0.546,1.781) \\
\text { Reference }\end{array}$ & \\
\hline Number of Primary Care Visits in past 12 months & & 0.3355 \\
\hline $\begin{array}{r}0 \\
1 \\
2-3 \\
4-5 \\
>=6\end{array}$ & $\begin{array}{l}\text { Reference } \\
0.970(0.698-1.348) \\
0.789(0.577-1.078) \\
0.945(0.647-1.379) \\
0.835(0.569-1.224)\end{array}$ & \\
\hline Number of Hepatitis B vaccine shots & & 0.0441 \\
\hline $\begin{array}{r}0 \\
1-2 \\
3 \\
>=4\end{array}$ & $\begin{array}{l}\text { Reference } \\
1.295(0.652,2.572) \\
1.655(\mathbf{1 . 0 3 5}, \mathbf{2 . 6 4 7 )} \\
\mathbf{2 . 3 4 3 ( 1 . 2 5 8 , 4 . 3 6 3 )}\end{array}$ & \\
\hline
\end{tabular}

${ }^{*}$ Weight was used to adjust for the dual sample frame of landline and cellphone and take into account these differences in the population.

*** In this study, "single" includes all those who are widowed, divorced, separated, and never married as well as those whose husbands are deceased.

${ }^{* * *}$ Poverty status is based on the 2009 Census poverty thresholds to calculate income-to-poverty ratio.

$\dagger$ Overall p-values for each variable indicate significant association between each variable and on-time initiation of HPV vaccine. 
Confounders for association between race/ethnicity, socioeconomic status, and health insurance status and on-time initiation of first HPV vaccine shot among 13-17 year-old females

Hispanics with married mothers had 1.170 (95\% CI: $0.841,1.628)$ odds of having an ontime first HPV shot than non-Hispanic Whites with married mothers (Table 4A). Hispanics with single mothers had 0.784 (95\% CI: $0.510,1.205)$ odds of having on-time first HPV shot than non-Hispanic Whites with single mothers (Table 4A). The crude odds ratio for Hispanics having higher odds than non-Hispanic Whites for on-time initiation of HPV vaccine series was 1.011 (95\% CI: $0.781,1.310)$ in Table 3. Since there were at least $10 \%$ differences between the crude odds ratio and the adjusted odds ratio, we considered the variable of "mother's marital status" as a confounder. The variable "marital status" was included in the multivariate logistic regression.

Additionally, previous literature had noted that family composition was associated with higher prevalence rates of HPV initiation $(20,21)$. Children who do not receive HPV vaccination were associated to having married mothers $(20,21)$. Since literature indicated that there was an association between the outcome (on-time initiation of HPV vaccination) and the confounding variable (mother's marital status), mother's marital status met the second criteria for confounder.

For the third criteria for confounding, marital status was not a part of the causal pathway between the exposure (marital status) and the outcome (on-time initiation of HPV vaccine series). For example, race/ethnicity did not cause someone's marital status to be either single or married. Likewise, someone's marital status did not cause either an on-time or late initiation of the first HPV vaccine shot. Therefore, marital status was not in the causal pathway between the exposure and the outcome, confirming the third criteria for confounder (Figure 2). 
Figure 2: Confounding variable assessment for marital status and exposure (race/ethnicity) and outcome (on-time initiation of the HPV vaccine series)

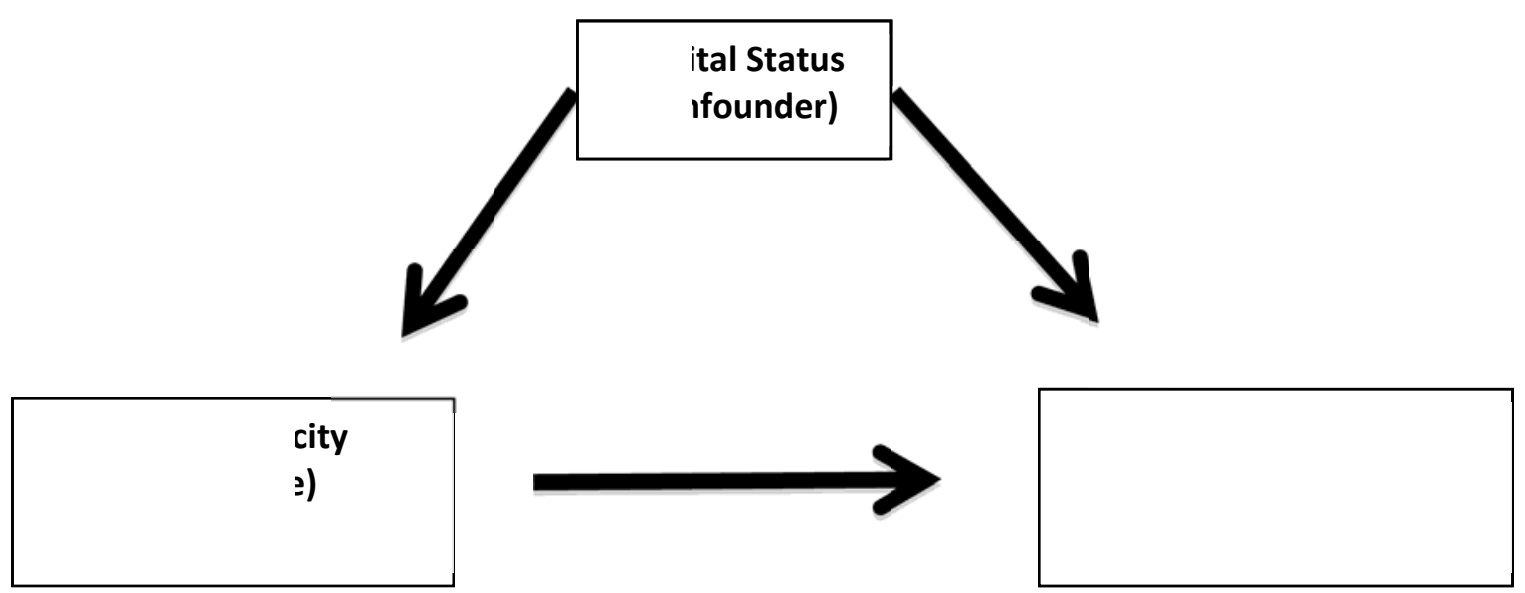

The same test was used to assess each of the confounding variables in Tables $4 \mathrm{~A}, 4 \mathrm{~B}, 4 \mathrm{C}$, and 4D. After examining each confounding variable, all of the crude ORs were at least 10\% (at least 0.01 ) different from the adjusted ORs. Therefore, these variables were all determined to fit the criteria for confounder and were adjusted for in the final analysis of this study. There was no evidence for any effect modifiers, based on our stratified analyses (Table 4A, 4B, 4C, and 4D). 
Table 4A: Stratified analysis of on-time initiation of first HPV vaccine by mother's marital status and race/ethnicity, mother's education, health insurance coverage, and poverty status in the United States, 2011

\begin{tabular}{|c|c|c|}
\hline \multirow[t]{2}{*}{$\begin{array}{l}\text { Variables: Mother's Marital Status by exposures } \\
\text { of interest }\end{array}$} & \multicolumn{2}{|c|}{$\begin{array}{c}\text { Mother's Marital Status } \\
* \text { Weighted Adjusted OR }(95 \% \mathrm{Cl})\end{array}$} \\
\hline & Single & Married \\
\hline \multicolumn{3}{|l|}{ Race/ethnicity } \\
\hline Hispanic & $0.784(0.510,1.205)$ & $1.170(0.841,1.628)$ \\
\hline Non-Hispanic White & Reference & Reference \\
\hline Non-Hispanic Black & $0.923(0.617,1.381)$ & $0.962(0.619,1.494)$ \\
\hline Non-Hispanic Other and Multi-Racial & $0.790(0.436,1.433)$ & $0.815(0.524,1.266)$ \\
\hline \multicolumn{3}{|l|}{ Mother's education } \\
\hline$<12$ years & Reference & Reference \\
\hline 12 years & $0.778(0.475,1.273)$ & $0.716(0.450,1.140)$ \\
\hline$>12$ years, non-college graduate & $1.189(0.739,1.912)$ & $0.622(0.405,0.956)$ \\
\hline College graduate & $0.565(0.336,0.951)$ & $0.613(0.407,0.921)$ \\
\hline \multicolumn{3}{|l|}{ Health Insurance Coverage } \\
\hline Private & $1.953(1.108,3.443)$ & $1.075(0.687,1.684)$ \\
\hline Public & $2.062(1.214,3.503)$ & $1.7(1.040,2.779)$ \\
\hline Other & $0.903(0.211,3.862)$ & $0.852(0.434,1.673)$ \\
\hline None & Reference & Reference \\
\hline \multicolumn{3}{|l|}{ Poverty status } \\
\hline Above poverty level $>\$ 75 \mathrm{~K}$ & $0.648(0.401,1.048)$ & $0.750(0.520,1.082)$ \\
\hline Above poverty level $\leq \$ 75 \mathrm{~K}$ & $0.676(0.467,0.978)$ & $0.798(0.537,1.187)$ \\
\hline Below poverty level & Reference & Reference \\
\hline
\end{tabular}

*Estimated using the logistic regression with four variables including race/ethnicity, mother's education, health insurance coverage, and poverty status 
Table 4B: Stratified analysis of on-time initiation of first HPV vaccine by number of children under 18 in household, race/ethnicity, mother's education, health insurance coverage, and poverty status in the United States, 2011

\begin{tabular}{|c|c|c|c|}
\hline \multirow[t]{2}{*}{$\begin{array}{l}\text { Variables: Number of children under } 18 \text { in } \\
\text { household by exposures of interest }\end{array}$} & \multicolumn{3}{|c|}{$\begin{array}{c}\text { Number of children under } 18 \text { in household } \\
\quad * \text { Weighted Adjusted OR }(95 \% \mathrm{Cl})\end{array}$} \\
\hline & 1 & $2-3$ & $>=4$ \\
\hline \multicolumn{4}{|l|}{ Race/ethnicity } \\
\hline Hispanic & $1.684(1.067,2.658)$ & $0.904(0.646,1.265)$ & $0.596(0.298,1.190)$ \\
\hline Non-Hispanic White & Reference & Reference & Reference \\
\hline Non-Hispanic Black & $1.023(0.656,1.596)$ & $0.785(0.521,1.183)$ & $1.524(0.709,3.273)$ \\
\hline Non-Hispanic Other and Multi-Racial & $0.882(0.516,1.505)$ & $0.697(0.419,1.158)$ & $1.471(0.658,3.287)$ \\
\hline \multicolumn{4}{|l|}{ Mother's education } \\
\hline$<12$ years & Reference & Reference & Reference \\
\hline 12 years & $0.419(0.234,0.750)$ & $1.004(0.632,1.595)$ & $0.794(0.329,1.915)$ \\
\hline$>12$ years, non-college graduate & $0.769(0.439,1.347)$ & $0.846(0.554,1.294)$ & $0.945(0.398,2.240)$ \\
\hline College graduate & $0.619(0.439,1.347)$ & $0.743(0.497,1.109)$ & $0.478(0.173,1.316)$ \\
\hline \multicolumn{4}{|l|}{ Health Insurance Coverage } \\
\hline 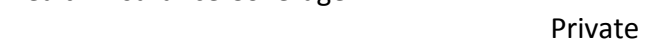 & $2.056(1.168,3.618)$ & $1.111(0.704,1.756)$ & $1.457(0.508,4.181)$ \\
\hline Public & $2.199(1.197,4.040)$ & $1.426(0.878,2.313)$ & $2.792(1.060,7.356)$ \\
\hline Other & $1.679(0.669,4.211)$ & $0.788(0.340,1.826)$ & $0.858(0.162,4.541)$ \\
\hline None & Reference & Reference & Reference \\
\hline \multicolumn{4}{|l|}{ Poverty status } \\
\hline Above poverty level $>\$ 75 \mathrm{~K}$ & $0.724(0.463,1.132)$ & $0.906(0.642,1.278)$ & $0.714(0.371,1.371)$ \\
\hline Above poverty level $\leq \$ 75 \mathrm{~K}$ & $0.773(0.488,1.222)$ & $0.951(0.660,1.370)$ & $0.397(0.186,0.847)$ \\
\hline Below poverty level & Reference & Reference & Reference \\
\hline
\end{tabular}

${ }^{*}$ Estimated using the logistic regression with four variables including race/ethnicity, mother's education, health insurance coverage, and poverty status 
Table 4C: Stratified analysis of on-time initiation of first HPV vaccine by number of primary care visits in the past 12 months, race/ethnicity, mother's education, health insurance coverage, and poverty status in the United States, 2011

\begin{tabular}{|c|c|c|c|c|c|}
\hline \multirow{2}{*}{$\begin{array}{l}\text { Variables: Number of primary care } \\
\text { visits in the past } 12 \text { months by } \\
\text { exposures of interest }\end{array}$} & \multicolumn{5}{|c|}{$\begin{array}{l}\text { Number of primary care visits in the past } 12 \text { months } \\
\qquad \text { Weighted Adjusted OR }(95 \% \mathrm{Cl})\end{array}$} \\
\hline & 0 & 1 & $2-3$ & $4-5$ & $>=6$ \\
\hline \multicolumn{6}{|l|}{ Race/ethnicity } \\
\hline Hispanic & $0.845(0.443,1.613)$ & $1.396(0.835,2.334)$ & $0.810(0.521,1.260)$ & $1.462(0.741,2.887)$ & $0.555(0.249,1.236)$ \\
\hline Non-Hispanic White & Reference & Reference & Reference & Reference & Reference \\
\hline Non-Hispanic Black & $0.601(0.277,1.304)$ & $0.968(0.560,1.674)$ & $0.790(0.494,1.262)$ & $1.561(0.727,3.350)$ & $1.352(0.557,3.279)$ \\
\hline Non-Hispanic Other and Multi-Racial & $0.419(0.175,1.000)$ & $1.239(0.654,2.346)$ & $0.912(0.542,1.536)$ & $0.587(0.193,1.788)$ & $0.759(0.300,1.917)$ \\
\hline \multicolumn{6}{|l|}{ Mother's education } \\
\hline$<12$ years & Reference & Reference & Reference & Reference & Reference \\
\hline 12 years & $0.712(0.310,1.635)$ & $1.2(0.595,2.422)$ & $0.629(0.359,1.103)$ & $0.521(0.196,1.390)$ & $1.022(0.391,2.673)$ \\
\hline$>12$ years, non-college graduate & $1.251(0.554,2.824)$ & $0.838(0.427,1.644)$ & $0.802(0.468,1.375)$ & $0.494(0.224,1.092)$ & $1.613(0.642,4.056)$ \\
\hline College graduate & $0.838(0.389,1.805)$ & $0.907(0.491,1.675)$ & $0.618(0.364,1.050)$ & $0.321(0.148,0.697)$ & $1.081(0.436,2.679)$ \\
\hline \multicolumn{6}{|l|}{ Health Insurance Coverage } \\
\hline Private & $2.153(0.662,7.00)$ & $1.525(0.728,3.195)$ & $1.376(0.822,2.304)$ & $0.640(0.267,1.533)$ & $1.847(0.706,4.833)$ \\
\hline Public & $2.921(0.879,9.703)$ & $1.897(0.868,4.144)$ & $1.700(0.983,2.941)$ & $0.978(0.384,2.492)$ & $2.517(0.952,6.652)$ \\
\hline Other & $0.811(0.180,3.655)$ & $0.908(0.302,2.731)$ & $2.012(0.785,5.159)$ & $0.545(0.102,2.914)$ & $0.856(0.106,6.888)$ \\
\hline None & Reference & Reference & Reference & Reference & Reference \\
\hline \multicolumn{6}{|l|}{ Poverty status } \\
\hline Above poverty level $>\$ 75 \mathrm{~K}$ & $1.136(0.606,2.130)$ & $0.642(0.385,1.068)$ & $0.701(0.472,1.039)$ & $0.583(0.280,1.212)$ & $1.133(0.566,2.269)$ \\
\hline Above poverty level $\leq \$ 75 \mathrm{~K}$ & $1.383(0.707,2.706)$ & $0.504(0.291,0.875)$ & $0.733(0.477,1.126)$ & $0.646(0.302,1.383)$ & $1.246(0.626,2.478)$ \\
\hline Below poverty level & Reference & Reference & Reference & Reference & Reference \\
\hline
\end{tabular}

"Estimated using the logistic regression with four variables including race/ethnicity, mother's education, health insurance coverage, and poverty status 
Table 4D: Stratified analysis of on-time initiation of first HPV vaccine by number of Hepatitis B shots, race/ethnicity, mother's education, health insurance coverage, and poverty status in the United States, 2011

\begin{tabular}{|c|c|c|c|c|}
\hline \multirow[t]{2}{*}{$\begin{array}{l}\text { Variables: Number of Hepatitis B shots by } \\
\text { exposures of interest }\end{array}$} & \multicolumn{4}{|c|}{$\begin{array}{c}\text { Number of Hepatitis B shots } \\
* \text { Weighted Adjusted OR }(95 \% \mathrm{Cl})\end{array}$} \\
\hline & 0 & $1-2$ & 3 & $>=4$ \\
\hline $\begin{array}{r}\text { Race/ethnicity } \\
\text { Hispanic } \\
\text { Non-Hispanic White } \\
\text { Non-Hispanic Black } \\
\text { Non-Hispanic Other and Multi-Racial }\end{array}$ & $\begin{array}{l}0.633(0.198,2.026) \\
\text { Reference } \\
0.428(0.118,1.551) \\
0.605(0.109,3.366)\end{array}$ & $\begin{array}{l}1.168(0.319,4.270) \\
\text { Reference } \\
1.350(0.402,4.536) \\
1.627(0.248,10.688)\end{array}$ & $\begin{array}{l}0.973(0.736,1.287) \\
\text { Reference } \\
0.988(0.723,1.350) \\
0.812(0.569,1.157)\end{array}$ & $\begin{array}{l}\mathbf{3 . 0 2 1}(\mathbf{1 . 1 1 4 , 8 . 1 9 3 )} \\
\text { Reference } \\
1.922(0.546,6.769) \\
1.319(0.429,4.060)\end{array}$ \\
\hline $\begin{array}{r}\text { Mother's education } \\
\qquad 12 \text { years } \\
12 \text { years } \\
>12 \text { years, non-college graduate } \\
\text { College graduate }\end{array}$ & $\begin{array}{l}\text { Reference } \\
1.189(0.334,4.232) \\
2.551(0.783,8.311) \\
0.858(0.23,3.207) \\
\end{array}$ & $\begin{array}{l}\text { Reference } \\
1.343(0.274,6.581) \\
0.656(0.15,2.875) \\
0.831(0.205,3.37) \\
\end{array}$ & $\begin{array}{l}\text { Reference } \\
0.733(0.504,1.066) \\
0.77(0.537,1.104) \\
\mathbf{0 . 6 3}(\mathbf{0 . 4 4 6 , 0 . 8 8 9 )} \\
\end{array}$ & $\begin{array}{l}\text { Reference } \\
0.931(0.26,3.338) \\
0.878(0.316,2.444) \\
0.884(0.323,2.417)\end{array}$ \\
\hline Health Insurance Coverage & $\begin{array}{l}1.44(0.364,5.698) \\
2.506(0.687,9.145) \\
\mathbf{3 7 . 8 3 6}(\mathbf{3 . 2 6 , 4 3 9 . 7 )} \\
\text { Reference }\end{array}$ & $\begin{array}{l}2.9(0.3,28.017) \\
3.534(0.384,32.53) \\
\quad- \\
\text { Reference }\end{array}$ & $\begin{array}{l}1.262(0.861,1.849) \\
1.615(1.08,2.416) \\
0.846(0.452,1.583) \\
\text { Reference }\end{array}$ & $\begin{array}{l}2.266(0.611,8.4) \\
4.726(1.242,17.9) \\
3.346(0.446,25.1) \\
\text { Reference }\end{array}$ \\
\hline $\begin{array}{r}\text { Above poverty level }>\$ 75 \mathrm{~K} \\
\text { Above poverty level } \leq \$ 75 \mathrm{~K} \\
\text { Below poverty level }\end{array}$ & $\begin{array}{l}1.009(0.27,3.77) \\
2.015(0.692,5.87) \\
\text { Reference }\end{array}$ & $\begin{array}{l}0.736(0.19,2.854) \\
1.432(0.417,4.924) \\
\text { Reference }\end{array}$ & $\begin{array}{l}0.720(0.553,0.938) \\
0.687(0.515,0.916) \\
\text { Reference }\end{array}$ & $\begin{array}{l}0.71(0.275,1.835) \\
0.707(0.27,1.85) \\
\text { Reference }\end{array}$ \\
\hline
\end{tabular}

${ }^{*}$ Estimated using the logistic regression with four variables including race/ethnicity, mother's education, health insurance coverage, and poverty status 


\section{Association between compliance with ACIP recommendations for age at initiation of the HPV vaccine series and socioeconomic status, race/ethnicity, and health insurance coverage}

Multivariate analysis was conducted to further evaluate the relationship between the exposure variables (mother's education, poverty status, race/ethnicity, and health insurance coverage) and on-time initiation of HPV vaccine series while controlling for confounders (Table 5). Variables were added to the multivariate logistic regression model to test for associations with the on-time initiation of first HPV shot and socioeconomic status, race/ethnicity, and health insurance coverage. All analyses incorporated the sample weight and survey design measures to ensure accurate interpretation of data.

\section{Socioeconomic status: On-time initiation of HPV vaccine series}

In the univariate analysis, those who were above poverty level, $\leq \$ 75 \mathrm{~K}$ had $0.75(95 \% \mathrm{CI}$ : $0.585,0.961)$ odds of initiating on-time, compared to those below poverty level (Table 3 ). Females who were above poverty level, $>\$ 75 \mathrm{~K}$ had $0.749(95 \% \mathrm{CI}: 0.575,0.975)$ odds of initiating on-time, compared to those below poverty level (Table 3). After adjusting for marital status, number of children in the household under age 18, number of primary care visits in past 12 months, and number of Hepatitis B vaccine shots in the multivariable analysis, females who were above poverty level, $>\$ 75 \mathrm{~K}$ had 0.746 (95\% CI: $0.568,0.980)$ odds of initiating on-time, compared to those below poverty level (Table 5).

Using the "mother's education" variable, those whose mothers were college graduates had 0.833 (95\% CI: $0.489,0.903)$ odds to initiate on-time compared to those whose mothers have less than 12 years of education in the univariate analysis (Table 3 ). In the multivariate analysis (after adjusting for marital status, number of children in the household under age 18, number of primary care visits in past 12 months, and number of Hepatitis B vaccine shots), females whose mothers were college graduates had 0.669 (95\% CI: $0.487,0.918)$ odds of 
initiating on-time compared to those whose mothers had less than 12 years of education (Table 5).

\section{Race/ethnicity: On-time initiation of HPV vaccine series}

Non-Hispanic Blacks and non-Hispanic Others and Multi-Racial were slightly less likely to initiate the HPV vaccine series on-time, compared to non-Hispanic Whites. In the univariate analysis, non-Hispanic Blacks had 0.971 (95\% CI: 0.731, 1.289) odds of initiating on-time than non-Hispanic Whites (Table 3). Non-Hispanic Others and Multi-Racial had 0.811 (95\% CI: $0.569,1.156$ ) odds of initiating on-time compared to non-Hispanic Whites (Table 3). Hispanics had 1.011 (95\% CI: $0.781,1.310)$ odds of initiating on-time compared to non-Hispanic Whites (Table 3).

In the multivariate analysis, Hispanics had 0.981 (95\% CI: 0.753, 1.277) odds of initiating on-time HPV vaccination compared to non-Hispanic Whites (Table 5). Non-Hispanic Blacks had 0.969 (95\% CI: 0.721, 1.302) while non-Hispanic Others and Multi-Racial had 0.828 ( $95 \%$ CI: $0.589,1.165)$ odds of initiating on-time HPV vaccination compared to non-Hispanic Whites (Table 5).

\section{Health insurance coverage: On-time initiation of HPV vaccine series}

Public health insurance coverage appeared to have a significant association with on-time initiation of HPV vaccine series. In the univariate analysis, females with public health insurance coverage had 1.826 (95\% CI: 1.274, 2.619) odds of initiating on-time than those with no health insurance (Table 3). Females who had private health insurance coverage were 1.379 (95\% CI: $0.978,1.945$ ) odds to initiate on-time, compared to those with no health insurance (Table 3). Those with health insurance coverage in the category of others had 0.970 (95\% CI: $0.546,1.781)$ odds of initiating on-time compared to those with no health insurance (Table 3). 
Similar results were reported in the multivariate analysis. Females with public health insurance coverage had 1.825 (95\% CI: 1.266, 2.631) odds of initiating on-time than females with no health insurance (Table 5). Females who had private health insurance coverage were 1.355 (95\% CI: $0.948,1.937)$ odds to initiate on-time, compared to females with no health insurance (Table 5). Females with other health insurance coverage had 0.964 (95\% CI: 0.524, 1.774) odds of initiating on-time than females with no health insurance (Table 5).

Table 5: Multivariate analysis of on-time HPV vaccine initiation among 13-17 year-old females who received at least one HPV vaccine shot in the United States, 2011

\begin{tabular}{|c|c|c|}
\hline Variables & $\begin{array}{l}\text { *Adjusted } \\
\text { OR (AOR) }\end{array}$ & $\begin{array}{l}\text { 95\% Confidence Interval } \\
\text { (CI) }\end{array}$ \\
\hline $\begin{array}{r}\text { Race/Ethnicity } \\
\text { Hispanic } \\
\text { Non-Hispanic White } \\
\text { Non-Hispanic Black } \\
\text { Non-Hispanic Other and Multi-Racial }\end{array}$ & $\begin{array}{l}0.981 \\
\text { Reference } \\
0.969 \\
0.828\end{array}$ & $\begin{array}{l}(0.753,1.277) \\
\text { Reference } \\
(0.721,1.302) \\
(0.589,1.165)\end{array}$ \\
\hline $\begin{array}{r}\text { Poverty status } \\
\qquad \begin{array}{r}\text { Above poverty level }>\$ 75 \mathrm{~K} \\
\text { Above poverty level } \leq \$ 75 \mathrm{~K} \\
\text { Below poverty level }\end{array}\end{array}$ & $\begin{array}{l}\mathbf{0 . 7 4 6} \\
0.77 \\
\text { Reference }\end{array}$ & $\begin{array}{l}(\mathbf{0 . 5 6 8 , 0 . 9 8 0 )} \\
(0.585,1.014) \\
\text { Reference }\end{array}$ \\
\hline $\begin{array}{r}\text { Mother's education } \\
<12 \text { years } \\
12 \text { years } \\
>12 \text { years, non-college graduate } \\
\text { College graduate }\end{array}$ & $\begin{array}{l}\text { Reference } \\
0.781 \\
0.837 \\
\mathbf{0 . 6 6 9}\end{array}$ & $\begin{array}{l}\text { Reference } \\
(0.557,1.095) \\
(0.606,1.157) \\
(\mathbf{0 . 4 8 7 , 0 . 9 1 8 )}\end{array}$ \\
\hline Health Insurance Coverage & $\begin{array}{l}1.355 \\
1.825 \\
0.964 \\
\text { Reference }\end{array}$ & $\begin{array}{l}(0.948,1.937) \\
(1.266,2.631) \\
(0.524,1.774) \\
\text { Reference }\end{array}$ \\
\hline
\end{tabular}

*Adjusted for 4 confounders, including marital status, number of children in the household under age 18, Number of Primary Care Visits in past 12 months, and Number of Hepatitis B vaccine shots 


\section{Sensitivity Analysis: Redefined “on-time” as 9-11 years olds and "late” as 14-17 years olds}

The majority of this study sample received their first HPV vaccine shot at the ages of 12 and 13 (age group $12=1,598$; age group $13=1,321$ ), according to Table 1 . Sensitivity analyses were performed to exclude the age groups 12 and 13 in the study sample.

Similar results were found for the weighted percentages of on-time and late initiators in the sensitivity analysis compared to the original analysis. Among females who received at least one HPV vaccine shot during 2011 ( $\mathrm{n}=3,046), 43.9 \%$ reported having received the first shot ontime while $56.1 \%$ reported having received the first shot late (Table 6A).

Table 6A: Sensitivity analysis for weighted percentages and numbers of on-time and late initiators among 13-17 year-old females who received at least one HPV vaccine shot in the United States, 2011 (excluded $12-13$ age groups)

\begin{tabular}{|c|c|c|c|}
\hline \multicolumn{4}{|c|}{ Sensitivity Analysis } \\
\hline $\begin{array}{l}\text { Age in years at time of } \\
\text { first HPV vaccine shot }\end{array}$ & $\begin{array}{l}\text { Number } \\
\text { in sample }\end{array}$ & $\begin{array}{l}{ }^{3} \text { Weighted } \\
\text { Frequency }\end{array}$ & $\begin{array}{l}{ }^{3} \text { Weighted } \\
\text { Percent }\end{array}$ \\
\hline${ }^{1}$ On-time & $\begin{array}{l}56 \\
193 \\
1145\end{array}$ & $\begin{array}{l}71911 \\
179472 \\
1002414\end{array}$ & $\begin{array}{l}2.5 \% \\
6.3 \% \\
35.1 \%\end{array}$ \\
\hline Total & 1394 & 1253797 & $43.9 \%$ \\
\hline $\begin{array}{l}14 \\
15 \\
16 \\
17\end{array}$ & $\begin{array}{l}914 \\
442 \\
216 \\
80\end{array}$ & $\begin{array}{l}860268 \\
417087 \\
257253 \\
68561\end{array}$ & $\begin{array}{l}30.1 \% \\
14.6 \% \\
9 \% \\
2.4 \%\end{array}$ \\
\hline Total & 1652 & 1603169 & $56.1 \%$ \\
\hline Total & 3046 & 2856966 & $100 \%$ \\
\hline
\end{tabular}

${ }^{1}$ Compliance of age at initiation of the HPV vaccine, defined as "on-time" vaccination based on the ACIP recommendation that the first of the three-dose HPV vaccine be given to girls by the ages of 11 or 12 years old. Children who received the first dose of HPV vaccination before or at the age of 12 are considered "on-time."

${ }^{2}$ Children who received the first dose of HPV vaccination after the age of 12 are considered "late."

${ }^{3}$ Weight was used to adjust for the dual sample frame of landline and cellphone and take into account these differences in the population.

Interesting and contrasting results were found for three variables in the sensitivity analysis when we excluded 12 and 13 year olds. Those who were above poverty level $>\$ 75 \mathrm{~K}$ had 1.344 (95\% CI: $1.035,1.745)$ odds of initiating on-time, compared to those below poverty level (Table 6B). Those whose mothers were college graduates had 1.418 (95\% CI: 1.067, 1.885) odds 
of initiating on-time compared to those whose mothers have less than 12 years of education in the univariate analysis (Table 6B). Private health insurance coverage appeared to have a significant association with on-time initiation of HPV vaccine series instead of public health insurance coverage in the original multivariate analysis. In the sensitivity analysis, females who had private health insurance coverage had 1.382 (95\% CI: 1.024, 1.866) odds of initiating ontime, compared to those with no health insurance (Table 6B).

Table 6B: Sensitivity analysis for multivariate analysis of on-time HPV vaccine initiation among 13-17 year-old females who received at least one HPV vaccine shot in the United States, 2011 (excluded $12-13$ age groups)

\begin{tabular}{|c|c|c|}
\hline \multicolumn{3}{|c|}{ Sensitivity Analysis } \\
\hline Variables & $\begin{array}{l}\text { *Adjusted } \\
\text { OR (AOR) }\end{array}$ & $\begin{array}{l}\text { 95\% Confidence Interval } \\
\text { (CI) }\end{array}$ \\
\hline $\begin{array}{r}\text { Race/Ethnicity } \\
\text { Hispanic } \\
\text { Non-Hispanic White } \\
\text { Non-Hispanic Black } \\
\text { Non-Hispanic Other and Multi-Racial }\end{array}$ & $\begin{array}{l}1.062 \\
\text { Reference } \\
0.853 \\
1.145\end{array}$ & $\begin{array}{l}(0.841,1.341) \\
\text { Reference } \\
(0.648,1.122) \\
(0.835,1.570)\end{array}$ \\
\hline $\begin{array}{r}\text { Above poverty level }>\$ 75 \mathrm{~K} \\
\text { Above poverty level } \leq \$ 75 \mathrm{~K} \\
\text { Below poverty level }\end{array}$ & $\begin{array}{l}1.344 \\
1.184 \\
\text { Reference }\end{array}$ & $\begin{array}{l}(\mathbf{1 . 0 3 5}, \mathbf{1 . 7 4 5 )} \\
(0.924,1.519) \\
\text { Reference }\end{array}$ \\
\hline $\begin{array}{r}\text { Mother's education } \\
\qquad 12 \text { years } \\
12 \text { years } \\
>12 \text { years, non-college graduate } \\
\text { College graduate }\end{array}$ & $\begin{array}{l}\text { Reference } \\
1.302 \\
1.289 \\
\mathbf{1 . 4 1 8}\end{array}$ & $\begin{array}{l}\text { Reference } \\
(0.954,1.778) \\
(0.956,1.737) \\
(\mathbf{1 . 0 6 7 , 1 . 8 8 5 )}\end{array}$ \\
\hline Health Insurance Coverage & $\begin{array}{l}1.382 \\
0.963 \\
1.382 \\
\text { Reference }\end{array}$ & $\begin{array}{l}(1.024,1.866) \\
(0.710,1.307) \\
(0.785,2.320) \\
\text { Reference }\end{array}$ \\
\hline
\end{tabular}

*Adjusted for 4 confounders, including marital status, number of children in the household under age 18, Number of Primary Care Visits in past 12 months, and Number of Hepatitis B vaccine shots 


\section{CHAPTER 6: DISCUSSION}

This study was one of the first studies focusing on timely initiation of the HPV vaccination series. Unlike much of the published research where the focus was mainly on initiation and completion of the HPV vaccination series, this study focused on compliance with ACIP recommendation regarding age at initiation.

Consistent with previous studies, females who had health insurance coverage were more likely to initiate on-time than those who did not have health insurance coverage $(20,21)$. Possible reasons for this finding could be that those with public health insurance may be more likely to go to a community clinic, where there have been efforts to increase HPV vaccination (20, 21). Public health insurance coverage, such as Vaccines for Children Program (VFC), Immunization Grant Program (Section 317), Medicaid, and Children's Health Insurance Program (CHIP) have helped to increase vaccine uptake for individuals who do not have health insurance $(26,27,28,29)$.

Consistent with previous studies, we found that females whose mothers were collegeeducated were significantly less likely to initiate on-time compared to those whose mothers had less than 12 years of education $(63,65,66)$. We also found that females whose family income were above poverty level were significantly less likely to initiate on-time compared to those who live below poverty level. Although women with higher SES are more likely to use preventive services compared to their counterparts $(75,76,77)$, several research studies have found that women with higher SES are also more likely to refuse or delay their children's vaccination (62, $63,65,66)$. Possible reasons for this finding could be that parents with higher education and income have heard, read, and/or saw negative aspects about the HPV vaccine in the news through outlets, such as television, radio, Internet, or newspapers (62). Those with higher 
education may be more likely to obtain a lot of information through various media channels (62). Information regarding HPV vaccination through these channels may be incorrect.

Misinformation could lead to confusion and even fear of obtaining HPV vaccination (62). Other reasons for delaying HPV vaccination are related to knowledge and belief of vaccine necessity (62). Some parents question the effectiveness of the HPV vaccine, believing that their children are not sexually active, or have concerns about lasting health problems (62). Because higher SES mothers tend to wait longer before allowing their children to initiate HPV vaccine, it could also provide an explanation why we see a difference in findings when the 12 and 13 year olds were dropped from the analysis.

Our study did not find race/ethnicity to be significantly associated with timely initiation of HPV vaccine series $(20,21)$. Focused on factors associated with overall initiation of HPV vaccination, Kessels and Fishers' studies found that Whites were more likely to initiate the HPV vaccine series compared to Hispanics and Blacks $(20,21)$. Kessels and Fishers' findings are inconsistent with a more recent study, where they found that Hispanics and Blacks were more likely to initiate the HPV vaccine series. More recent studies also found that White parents are most likely to delay and refuse the HPV vaccine series for their children $(62,63,65)$. The inconsistencies across studies' results for the association between race/ethnicity and HPV vaccine initiation could explain the reason why we did not find a significant result for race/ethnicity in this study. High refusal of all childhood vaccines among White mothers who were college-educated and earned high incomes has been previously noted $(63,67)$. They may have lower perceived need for HPV vaccination due to higher access to regular cervical cancer screening $(63,67)$. 


\section{Implications and Future Research}

The importance of HPV vaccination, especially on-time vaccination, deserves much attention by healthcare providers, parents, public health officials, policy makers, and all other HPV vaccination stakeholders. CDC estimates that only $30 \%$ of U.S. females received all three HPV doses by 13-15 years of age $(13,14)$. Of those who received at least one HPV vaccine shot, this study found that less than half (47.7\%) complied with ACIP recommendation and received the first shot on-time (Table 1). To increase on-time HPV vaccination rates, evidence-based strategies should be adopted (74). For instance, healthcare providers should provide strong, clear, and consistent ACIP recommendation for HPV vaccine to parents (74). Policy makers can also address out-of-pocket expenses in the existing public insurance programs. These expenses could be associated with transportation fees or missed workday's compensation (74).

Future research is also needed to investigate the reason why we see contrasting results between analyses defining "on-time" initiators as 9-12 year-olds and in accordance to ACIPrecommended age at initiation $(1,10,11,12)$ versus analyses that excluded children age 12 yearolds. Multivariate analysis found that people who initiated on time are more likely to have public health insurance. People who live above poverty and whose mothers finished college are less likely to be on time. In contrast, sensitivity analysis excluding age 12 year-olds found higher SES and those with private health insurance are more likely to be on time, compared to their counterpart. Results vary based on how "on-time" initiation is defined.

Further research is required to explore barriers associated with specific populations identified in this study as having lower on-time initiation. People who initiated on time are more likely to have public health insurance. People who live above poverty and whose mothers finished college are less likely to be on time. We need more research to focus in this area and dig deeper into the reasons why we see lower on-time initiation rates among these subgroups. 
Targeted interventions and policies can be developed to increase on-time initiators of HPV vaccination in the U.S.

\section{Strengths}

There were several strengths in using the NIS -Teen dataset. In the U.S., the 2011 NIS Teen dataset has been one of the best public health surveillance tools available for vaccination data. It provides us with a large, nationally representative sample size of children in the U.S. as well as information on the HPV vaccine uptake (42).

Additionally, the 2011 NIS-Teen has a strong and comprehensive survey study design using random-digit-dial telephone survey for the households combined with the mail survey for the vaccination providers (42). Vaccination information from the providers is more likely to be up-to-date, complete, and reliable than household-reported information (53). The combination of the household-reported data and the provider-reported data provides a unique step to validate and ensure the accuracy of the HPV vaccination data.

\section{Limitations}

Several limitations of this study exist. First, this study's analysis was limited by the variables included in the 2011 NIS-Teen Public Use Data File. The 2011 NIS-Teen only asked questions of mothers' marital status and education but not fathers'. We were not able to exclude children who already have HPV infection at the time of the study. The 2011 NIS-Teen only asked parents and providers to provide dates when children received HPV vaccination, but no biological samples were collected to check for their HPV infection status.

Second, the nature of the cross-sectional study design inhibited the ability to make direct causal inferences. Although direct causal relationships cannot be inferred from this crosssectional study, this study still provides us with useful insight of the associations between our 
independent variables (mother's education, poverty status, race/ethnicity, health insurance status) and dependent variable (on-time initiation of HPV vaccination).

Lastly, this study was limited to the most recent publically available data from the NIS Teen at the time of my proposal defense. NIS-Teen surveys were also conducted during 2012 and 2013, but the 2012 NIS-Teen dataset was not available for public use until the end of December 2013. This limitation hindered our ability to assess more recent changes in HPV vaccination. With the implementation of the ACA, we are expecting rapid changes in health insurance coverage and many routine preventive services in the United States $(27,34,35)$.

\section{Public Health Significance}

Timeliness for initiating the HPV vaccine series is essential in order to prevent cervical cancer $(10,47,68,69,70)$. It is crucial to follow the ACIP recommendation regarding age at initiation of HPV vaccine series (HPV vaccination should be started at 11 or 12 years of age, but it can be started 9 years of age) to ensure that vaccinations are given at the correct timeline for optimal protection (47). Vaccinations are some of the most important public health tools available for preventing diseases $(31,32)$. Not only does vaccination protect children from developing potentially serious diseases, but they also protect the community by reducing the spread of infectious diseases $(31,32)$.

Healthy People 2020 recognizes the importance of HPV vaccination through two objectives to increase HPV vaccination uptake (IID-11.4) and to reduce HPV infection (STI-9) $(13,14)$. To achieve these objectives, compliance with ACIP recommendation regarding age at initiation will help increase overall HPV vaccination rates, increase protection against HPV infection, and potentially decrease the risk of cervical cancer in adulthood $(13,14)$. Because the most effective time to vaccinate is prior to exposure of HPV infection, late initiation of HPV 
vaccination leaves children with a longer window of vulnerability to contract HPV infection (52, 68, 69, 70). 


\section{APPENDICES}

Appendix A: List of Variables used in this study, NIS-Teen, 2011

\begin{tabular}{|c|c|c|c|c|c|}
\hline Variable Name & Description & Label in dataset & Type & $\begin{array}{l}\text { How variables are categorized in } \\
\text { NIS-Teen } 2011 \text { dataset }\end{array}$ & $\begin{array}{l}\text { How I categorized variables for } \\
\text { this study }\end{array}$ \\
\hline HPV_AGE1 & Age in provider reports & $\begin{array}{l}\text { Age of teens in years of } \\
\text { PROVIDER-reported first human } \\
\text { papillomavirus shot }\end{array}$ & Categorical & $\begin{array}{l}\text { 0-18 } \\
\text { (Mean: 13.0, Median: 13.0, Min: } \\
\text { 0.0, Max: 18.0, STD Dev.: 1.7) }\end{array}$ & $\begin{array}{l}\text { Age in years at time of first HPV } \\
\text { shot: } \\
-9 \\
-10 \\
-11 \\
-12 \\
-13 \\
-14 \\
-15 \\
-16 \\
-17\end{array}$ \\
\hline HPVI_AGE_SC1 & Age in household reports & $\begin{array}{l}\text { Age of teen in years at } \\
\text { Household-reported first human } \\
\text { papillomavirus shot }\end{array}$ & Categorical & N/A & N/A \\
\hline AGE & Age, at the time of interview & Age in years of selected teen & Categorical & $13,14,15,16,17$ & $\begin{array}{l}\text { Age: } \\
-13 \\
-14 \\
-15 \\
-16 \\
-17\end{array}$ \\
\hline SEX & Sex & Gender of child & Categorical & $\begin{array}{l}\text { 1=Male } \\
\text { 2=Female } \\
\text { 77=Don't Know, } \\
\text { 99=Refused }\end{array}$ & $\begin{array}{l}\text { Sex: } \\
\text {-Male } \\
\text {-Female }\end{array}$ \\
\hline RACEETHK & Race/Ethnicity & $\begin{array}{l}\text { Race/Ethnicity Of Teen With } \\
\text { Multi-race Category (Recode) }\end{array}$ & Categorical & $\begin{array}{l}\text { 1= Hispanic, } \\
\text { 2=Non-Hispanic White Only, } \\
\text { 3=Non-Hispanic Black Only, } \\
\text { 4=Non-Hispanic Other + Multiple } \\
\text { Race } \\
\text { 77=Don't Know, } \\
\text { 99=Refused }\end{array}$ & $\begin{array}{l}\text { Race/Ethnicity: } \\
\text {-Hispanic } \\
\text {-Non-Hispanic White Only } \\
\text { (reference) } \\
\text {-Non-Hispanic Black Only } \\
\text {-Non-Hispanic Other And Multi- } \\
\text { Racial }\end{array}$ \\
\hline
\end{tabular}




\begin{tabular}{|c|c|c|c|c|c|}
\hline MARITAL2 & Mother's Marital Status & $\begin{array}{l}\text { Marital Status Of Mother } \\
\text { (Recode) }\end{array}$ & Categorical & $\begin{array}{l}\text { 1=Married, } \\
\text { 2=Never } \\
\text { Married/Widowed/Divorced/Sep } \\
\text { arated/Decreased } \\
\text { 77=Don't Know, } \\
\text { 99=Refused }\end{array}$ & $\begin{array}{l}\text { Mother's Marital Status: } \\
\text { - Single (reference) } \\
\text { - Married }\end{array}$ \\
\hline CHILDNM & $\begin{array}{l}\text { Number Of Children In The } \\
\text { Household Under Age } 18\end{array}$ & $\begin{array}{l}\text { Number Of Children Under } 18 \\
\text { Years Of Age In HH (Recode) }\end{array}$ & Categorical & $\begin{array}{l}\text { 1=One, } \\
\text { 2= Two Or Three, } \\
\text { 3=Four Or More } \\
\text { 77=Don't Know, } \\
\text { 99=Refused }\end{array}$ & $\begin{array}{l}\text { Number Of Children In The } \\
\text { Household Under Age 18: } \\
-1 \\
-2-3 \\
-\geq 4 \text { (reference) }\end{array}$ \\
\hline INCPOV1 & Poverty Status & Poverty Status & Categorical & $\begin{array}{l}\text { 1=Above Poverty }>\$ 75 \mathrm{k}, \\
2=\text { Above Poverty }<=\$ 75 \mathrm{k}, \\
\text { 3=Below Poverty, } \\
\text { 4=Unknown } \\
\text { 77=Don't Know, } \\
\text { 99=Refused }\end{array}$ & $\begin{array}{l}\text { Poverty Status: } \\
\text { - Above Poverty Level }>\$ 75 \mathrm{k} \\
\text { - Above Poverty Level } \leq \$ 75 \mathrm{k} \\
\text { - Below Poverty Level (reference) }\end{array}$ \\
\hline EDUC1 & Mother's Education & $\begin{array}{l}\text { Education Level Of Mother With } \\
4 \text { Categories (Recode) }\end{array}$ & Categorical & $\begin{array}{l}\text { 1=Less Than } 12 \text { Years, } \\
\text { 2=12 Years, } \\
\text { 3=More Than } 12 \text { Years, Non- } \\
\text { College Grad, } \\
\text { 4=College Graduate } \\
\text { 77=Don't Know, } \\
\text { 99=Refused }\end{array}$ & $\begin{array}{l}\text { Mother's Education: } \\
\text { - }<12 \text { Years (reference) } \\
\text { - } 12 \text { Years } \\
\text { - >12 Years, Non-College Graduate } \\
\text { - College Graduate }\end{array}$ \\
\hline TIS_INS_1 & \multirow[t]{4}{*}{ Health insurance coverage } & $\begin{array}{l}\text { Is teen covered by health } \\
\text { insurance provided through } \\
\text { employer or union? } \\
\text { (Private) }\end{array}$ & \multirow[t]{4}{*}{ Categorical } & \multirow[t]{4}{*}{$\begin{array}{l}\text { 1=Yes, } \\
2=\text { =No, } \\
\text { 77=Don't Know, } \\
\text { 99= Refused }\end{array}$} & \multirow[t]{4}{*}{$\mathrm{N} / \mathrm{A}$} \\
\hline TIS_INS_2 & & $\begin{array}{l}\text { Is the teen covered by any } \\
\text { Medicaid plan? } \\
\text { (Public) }\end{array}$ & & & \\
\hline TIS_INS_3 & & $\begin{array}{l}\text { Is The Teen Covered By S-Chip? } \\
\text { (Public) }\end{array}$ & & & \\
\hline TIS_INS_3A & & $\begin{array}{l}\text { Is The Teen Covered By Any } \\
\text { Medicaid Plan Or S-Chip? }\end{array}$ & & & \\
\hline
\end{tabular}




\begin{tabular}{|c|c|c|c|c|c|}
\hline & & (Public) & & & \\
\hline TIS_INS_4_5 & & $\begin{array}{l}\text { Is the teen covered by Indian } \\
\text { health service, Military health } \\
\text { care, Tricare, Champus, or } \\
\text { Champ-VA } \\
\text { (Other) }\end{array}$ & & & \\
\hline TIS_INS_6 & & $\begin{array}{l}\text { Is The Teen Covered By Any } \\
\text { Other Health Insurance Or Health } \\
\text { Care Plan } \\
\text { (Other) }\end{array}$ & & & \\
\hline TIS_INS_11 & & $\begin{array}{l}\text { Since age } 11 \text {, was there any time } \\
\text { when the teen was not covered } \\
\text { by health insurance? (None) }\end{array}$ & & & \\
\hline INS_TYPE & $\begin{array}{l}\text { Health insurance coverage (re- } \\
\text { categorization) }\end{array}$ & $\begin{array}{l}\text { Using definition from the U.S. } \\
\text { Census Bureau and suggestion } \\
\text { from CDC data manager, this } \\
\text { variable was categorized into } \\
\text { private, public, other, and none }\end{array}$ & Categorical & $\begin{array}{l}\text { None }=0 \\
\text { Public }=1 \\
\text { Private }=2 \\
\text { Other }=3 \\
\text { 77=Don't Know, } \\
\text { 99=Refused }\end{array}$ & $\begin{array}{l}\text { Health Insurance Coverage: } \\
\text {-Private } \\
\text {-Public } \\
\text {-Other } \\
\text { - None (reference) }\end{array}$ \\
\hline VISITS & $\begin{array}{l}\text { Number Of Primary Care Visits } \\
\text { In Past } 12 \text { Months }\end{array}$ & $\begin{array}{l}\text { In Past } 12 \text { Months Number Of } \\
\text { Times Teen Has Seen A Doctor Or } \\
\text { Other Health Care Professional }\end{array}$ & Categorical & $\begin{array}{l}1=\text { None, } \\
2=1, \\
3=2-3, \\
4=4-5, \\
5=6-7, \\
6=8-9, \\
7=10-12, \\
8=13-15, \\
9=16+, \\
77=\text { Don't Know, } \\
99=\text { Refused }\end{array}$ & N/A \\
\hline
\end{tabular}




\begin{tabular}{|c|c|c|c|c|c|}
\hline VISITS_VAR & $\begin{array}{l}\text { Number Of Primary Care Visits } \\
\text { In Past } 12 \text { Months (re- } \\
\text { categorization) }\end{array}$ & $\begin{array}{l}\text { In Past } 12 \text { Months Number Of } \\
\text { Times Teen Has Seen A Doctor Or } \\
\text { Other Health Care Professional }\end{array}$ & Categorical & $\begin{array}{l}1=0, \\
2=1, \\
3=2-3, \\
4=4-5, \\
5=6,7,8,9,10,11,12,13,14,15, \\
16+, \\
77=\text { Don't Know, } \\
99=\text { Refused }\end{array}$ & $\begin{array}{l}\text { Number Of Primary Care Visits In } \\
\text { Past } 12 \text { Months: } \\
-0 \text { (reference) } \\
-1 \\
-2-3 \\
-4-5 \\
-6+\end{array}$ \\
\hline P_N13HEPB & $\begin{array}{l}\text { Number Of Hepatitis B Vaccine } \\
\text { Shots }\end{array}$ & $\begin{array}{l}\text { Number Of Hepatitis B- } \\
\text { Containing Shots By Age } 13 \text { Years } \\
\text { Determined From Provider Info, } \\
\text { Excluding Any Vaccinations After } \\
\text { The RDD Interview Date. }\end{array}$ & Categorical & $\begin{array}{l}0=0, \\
1=1, \\
2=2, \\
3=3, \\
4=4, \\
5=5, \\
6=6, \\
7=7, \\
77=\text { Don't Know, } \\
99=\text { Refused }\end{array}$ & $\mathrm{N} / \mathrm{A}$ \\
\hline $\begin{array}{l}\text { P_N13HEPB_V } \\
\text { AR }\end{array}$ & $\begin{array}{l}\text { Number Of Hepatitis B Vaccine } \\
\text { Shots (re-categorization) }\end{array}$ & $\begin{array}{l}\text { Number Of Hepatitis B- } \\
\text { Containing Shots By Age } 13 \text { Years } \\
\text { Determined From Provider Info, } \\
\text { Excluding Any Vaccinations After } \\
\text { The RDD Interview Date. }\end{array}$ & Categorical & $\begin{array}{l}1=0, \\
2=1,2, \\
3=3, \\
4=4,5,6,7, \\
77=\text { Don't Know, } \\
99=\text { Refused }\end{array}$ & $\begin{array}{l}\text { Number of Hepatitis B vaccine } \\
\text { shots: } \\
-0 \text { (reference) } \\
-1-2 \\
-3 \\
-4+\end{array}$ \\
\hline COMPSTATUS & Compliance Status & $\begin{array}{l}\text { If variable "Hpv_Age1" is } \\
\text { between } 9-12 \text { then variable } \\
\text { "CompStatus"="On-time". If } \\
\text { variable "Hpv_Age1" is between } \\
12-17, \text { then variable } \\
\text { "CompStatus"="Late". }\end{array}$ & Categorical & $\begin{array}{l}\text { "On-time" = } 1 \\
\text { "Late" = } 0\end{array}$ & $\begin{array}{l}\text { "On-time" = 9, 10, 11, } 12 \\
\text { "Late" = 13, 14, 15, 16, } 17\end{array}$ \\
\hline PROVWT_D & $\begin{array}{l}\text { Weight variable used to adjust } \\
\text { for the dual sample frame of } \\
\text { landline and cell phones (42) }\end{array}$ & $\mathrm{N} / \mathrm{A}$ & $\mathrm{N} / \mathrm{A}$ & $\mathrm{N} / \mathrm{A}$ & $\mathrm{N} / \mathrm{A}$ \\
\hline
\end{tabular}


Appendix B: Weighted Frequencies by age group among NIS-Teen, 2011

\begin{tabular}{|r|r|r|}
\hline \multicolumn{3}{|c|}{ AGE IN YEARS OF SELECTED TEEN } \\
\hline \multicolumn{1}{|r|}{ AGE } & Frequency & Percent \\
\hline 13 & 7602 & $19.55 \%$ \\
\hline 14 & 7894 & $19.89 \%$ \\
\hline 15 & 7827 & $20.22 \%$ \\
\hline 16 & 8030 & $20.80 \%$ \\
\hline 17 & 7514 & $19.53 \%$ \\
\hline Total & 38867 & $100 \%$ \\
\hline
\end{tabular}

Appendix C: Weighted Frequencies by sex among NIS-Teen, 2011

\begin{tabular}{|c|c|c|}
\hline \multicolumn{3}{|c|}{ GENDER OF SELECTED TEEN } \\
\hline SEX & Frequency & Percent \\
\hline Male & 20809 & $52.23 \%$ \\
\hline Female & 19030 & $47.77 \%$ \\
\hline Total & 39839 & $100 \%$ \\
\hline
\end{tabular}

Appendix D: Test for Multicollinearity for Variables of Mother's education, Poverty status, Race/ethnicity, and Health insurance status

\begin{tabular}{|c|c|c|c|c|c|c|c|c|}
\hline \multicolumn{9}{|c|}{ Parameter Estimates } \\
\hline Variable & Label & DF & $\begin{array}{r}\text { Parameter } \\
\text { Estimate }\end{array}$ & $\begin{array}{r}\text { Standard } \\
\text { Error }\end{array}$ & t Value & $\operatorname{Pr}>|t|$ & Tolerance & $\begin{array}{l}\text { Variance } \\
\text { Inflation }\end{array}$ \\
\hline Intercept & Intercept & 1 & 0.55673 & 0.03662 & 15.20 & $<.0001$ & $\cdot$ & 0 \\
\hline RACEETHK & $\begin{array}{l}\text { RACE/ETHNICITY OF TEEN WITH } \\
\text { MULTIRACE CATEGORY (RECODE) }\end{array}$ & 1 & -0.01559 & 0.00808 & -1.93 & 0.0538 & 0.99345 & 1.00659 \\
\hline EDUC1 & $\begin{array}{l}\text { EDUCATION LEVEL OF MOTHER } \\
\text { WITH } 4 \text { CATEGORIES (RECODE) }\end{array}$ & 1 & -0.01978 & 0.00721 & -2.74 & 0.0061 & 0.73696 & 1.35692 \\
\hline INCPOV1 & POVERTY STATUS & 1 & 0.01912 & 0.00875 & 2.18 & 0.0290 & 0.73965 & 1.35199 \\
\hline INS_TYPE & & 1 & 0.00035871 & 0.00219 & 0.16 & 0.8702 & 0.99279 & 1.00726 \\
\hline
\end{tabular}


Appendix E: MPH Competencies address in thesis

\begin{tabular}{|c|c|c|c|}
\hline & $\begin{array}{l}\text { Competencies for MPH in } \\
\text { Epidemiology }\end{array}$ & Thesis & Addressed in this Thesis \\
\hline 1) & $\begin{array}{l}\text { Demonstrate the importance of } \\
\text { epidemiology for informing } \\
\text { scientific, ethical, economic, } \\
\text { and political discussion of } \\
\text { health issues. }\end{array}$ & $\checkmark$ & $\begin{array}{l}\text { Epidemiologic analysis of variables associated with } \\
\text { compliance at age at initiation in the HPV vaccine } \\
\text { series and the public health significance of this study } \\
\text { with suggestions for possible policy applications }\end{array}$ \\
\hline 2) & $\begin{array}{l}\text { Assess a public health problem } \\
\text { in terms of magnitude, person, } \\
\text { time and place. }\end{array}$ & $\checkmark$ & $\begin{array}{l}\text { Examine factors associated with on-time initiation of } \\
\text { HPV vaccine series among 13-17 year-old females in } \\
\text { the U.S. in } 2011\end{array}$ \\
\hline 3) & $\begin{array}{l}\text { Distinguish the basic } \\
\text { terminology and definitions of } \\
\text { epidemiology. }\end{array}$ & $\checkmark$ & Statistical analysis and interpretation of results. \\
\hline 4) & $\begin{array}{l}\text { Discriminate key sources of } \\
\text { data for epidemiological } \\
\text { purposes. }\end{array}$ & $\checkmark$ & Use of 2011 NIS-Teen, strengths, and limitations \\
\hline 5) & $\begin{array}{l}\text { Calculate basic epidemiology } \\
\text { measures. }\end{array}$ & $\checkmark$ & $\begin{array}{l}\text { Descriptive statistics displaying socio-demographic } \\
\text { characteristics in the sample among 13-17 year-old } \\
\text { females who received at least one HPV vaccine shot }\end{array}$ \\
\hline 6) & $\begin{array}{l}\text { Identify the principles and } \\
\text { limitations of public health } \\
\text { screening programs. }\end{array}$ & $\checkmark$ & $\begin{array}{l}\text { Preventive services for cervical cancer, such as Pap } \\
\text { smear test and HPV vaccine }\end{array}$ \\
\hline 7) & $\begin{array}{l}\text { Evaluate strengths and } \\
\text { limitations of epidemiologic } \\
\text { reports. }\end{array}$ & $\checkmark$ & $\begin{array}{l}\text { Strengths and weaknesses in introduction and } \\
\text { discussion sections }\end{array}$ \\
\hline 8) & $\begin{array}{l}\text { Draw appropriate inferences } \\
\text { from epidemiologic data. }\end{array}$ & $\checkmark$ & Results and discussion sections \\
\hline 9) & Explain criteria for causality & $\checkmark$ & Results and discussion sections (e.g. limitations) \\
\hline & $\begin{array}{l}\text { Calculate advanced } \\
\text { epidemiologic measures. }\end{array}$ & $\checkmark$ & $\begin{array}{l}\text { Univariate analysis, stratified analysis, and } \\
\text { multivariate analysis to calculate odds ratios. } \\
\text { Confidence interval is also included. }\end{array}$ \\
\hline & $\begin{array}{l}\text { Communicate epidemiologic } \\
\text { information to lay and } \\
\text { professional audiences. }\end{array}$ & $\checkmark$ & $\begin{array}{l}\text { Written thesis report; oral thesis defense and final } \\
\text { presentation of results and public health significance } \\
\text { to audiences }\end{array}$ \\
\hline 12) & $\begin{array}{l}\text { Compare basic ethical and legal } \\
\text { principles pertaining to the } \\
\text { collection, maintenance, use } \\
\text { and dissemination of } \\
\text { epidemiologic data. }\end{array}$ & $\checkmark$ & $\begin{array}{l}\text { Discuss NIS-teen confidentiality and voluntary } \\
\text { topics; obtain IRB approval before data analysis } \\
\text { process. }\end{array}$ \\
\hline 13) & $\begin{array}{l}\text { Design, analyze, and evaluate } \\
\text { an epidemiologic study. }\end{array}$ & $\checkmark$ & Design, conduct and write up thesis \\
\hline 14) & $\begin{array}{l}\text { Design interventions to reduce } \\
\text { prevalence of major public } \\
\text { health problems. }\end{array}$ & $\checkmark$ & $\begin{array}{l}\text { Discuss public health significance, future research } \\
\text { and policy interventions to increase compliance to } \\
\text { age at initiation of HPV vaccine series }\end{array}$ \\
\hline
\end{tabular}




\section{REFERENCES}

1. Centers for Disease Control and Prevention. Advisory Commitee on Immunization Practices (ACIP): Quadrivalent Human Papillomavirus Vaccine.MMWR Morb Mortal Wkly Rep 2007;56(RR02): 1-24.

2. Division of STD Prevention. HPV Vaccine Information for Clinicians - Fact Sheet [Internet]. 2012 [cited 2013 Oct 15]. Available from: http://www.cdc.gov/std/hpv/stdfacthpv-vaccine-hcp.htm.

3. Emory University. Cervical Cancer: Risk Factors [Internet]. CancerQuest; 2012 [cited 2013 April 10]. Available from: http://www.cancerquest.org/cervical-cancer-risks.html.

4. World Health Organization. Human papillomavirus (HPV) [Internet]. 2010 [cited 2013 Oct 15]. Available from: http://www.who.int/immunization/topics/hpv/en.

5. Kim J, Goldie S. Health and Economic Implications of HPV Vaccination in the United States. N Engl J Med 2008;359: 821-32.

6. Sanders G, Taira A. Cost Effectiveness of a Potential Vaccine for Human Papillomavirus. Emerging Infectious Diseases. 2003;9(1): 37-48.

7. U.S. Food and Drug Administration. Cervarix [Internet]. 2013 [cited 2013 Oct 15]. Available from: http://www.fda.gov/biologicsbloodvaccines/vaccines/approvedproducts/ucm186957.htm.

8. U.S. Food and Drug Administration. Gardasil [Internet]. 2013 [cited 2013 Oct 15]. Available from: http://www.fda.gov/BiologicsBloodVaccines/Vaccines/ApprovedProducts/ucm094042.ht $\mathrm{m}$.

9. National Center for Immunization and Respiratory Diseases. Human Papillomavirus (HPV) ACIP Vaccine Recommendations [Internet]. 2013 [cited 2013 Oct 15]. Available from: http://www.cdc.gov/vaccines/hcp/acip-recs/vacc-specific/hpv.html.

10. Centers for Disease Control and Prevention. FDA Licensure of Bivalent Human Papillomavirus Vaccine (HPV2, Cervarix) for Use in Females and Updated HPV Vaccination Recommendations from the Advisory Committee on Immunization Practices (ACIP).MMWR Morb Mortal Wkly Rep. 2010;59(20):626-629.

11. Centers for Disease Control and Prevention. FDA Licensure of Quadrivalent Human Papillomavirus Vaccine (HPV4, Gardasil) for Use in Males and Guidance from the Advisory Committee on Immunization Practices (ACIP). MMWR Morb Mortal Wkly Rep. 2010;59(20):630-632.

12. Centers for Disease Control and Prevention. Recommendations on the use of 
quadrivalent human papillomavirus vaccine in males-Advisory Committee on Immunization Practices (ACIP) .MMWR Morb Mortal Wkly Rep. 2011;60(50):17051708.

13. U.S. Department of Health and Human Services. About Health People. [Internet]. 2012 [cited 2013 Oct 15]. Available from:

http://www.healthypeople.gov/2020/about/default.aspx.

14. National Immunization Survey (NIS). DATA2020 Search Results: Immunization and Infectious Diseases -IID-11.4 Increase the vaccination coverage level of 3 doses of human papillomavirus (HPV) vaccine for females by age 13 to 15 years [Internet]. 2011 [cited 2014 Feb 7]. Available from: http://www.healthypeople.gov/2020/Data/SearchResult.aspx?topicid=23\&topic=Immuniz ation\%20and\%20Infectious\%20Diseases\&objective=IID-11.4\&anchor=567809.

15. National Institutes of Health. Cervical Cancer. NIH Consensus Statement [Internet]. 1996;14(1):1-38. [cited 2013 Oct 30]. Available from: http://www.cdc.gov/cancer/cervical/statistics.

16. Niccolai L, Mehta N, Hadler J. Racial/Ethnic and Poverty Disparities in Human Papillomavirus Vaccination Completion. Am J Prev Med. 2011;41(4):428-433. doi: 10.1016/j.amepre.2011.06.032.

17. Downs L, Smith J, Scarinci I, Flowers L, Parham,G. The disparity of cervical cancer in diverse populations. Gynecologic Oncology. 2008;109(2), Supplement:S22-S30, Available from: http://www.sciencedirect.com/science/article/pii/S009082580800005X.

18. Cook RL, Zhang J, Mullins J, Kauf T, Brumback B, Steingraber H. Factors associated with initiation and completion of human papillomavirus vaccine series among young women enrolled in Medicaid. Journal of Adolescent Health. 2010;47(6):596-9.

19. Chao C, Velicer C, Slezak JM, Jacobsen SJ. Correlates for human papillomavirus vaccination of adolescent girls and young women in a managed care organization. American Journal of Epidemiology. 2010;171(3):357-67.

20. Kessels SJ, Marshall HS, Watson M, Braunack-Mayer AJ, Reuzel R, Tooher, RL. Factors associated with HPV vaccine uptake in teenage girls: a systematic review. Vaccine. 2012;30(24): 3546-56. doi: 10.1016/j.vaccine.2012.03.063.

21. Fisher, H., Trotter, C., Audrey, S., Macdonald-Wallis, K., \& Hickman, M. Inequalities in the uptake of Human Papillomavirus Vaccination: a systematic review and meta-analysis. International Journal of Epidemiology. 2013; 42:896-908. doi:10.1093/ije/dyt049.

22. Dombkowski KJ, Lantz PM, Freed GL. Role of health insurance and a usual source of medical care in age-appropriate vaccination. Am J Public Health. 2004;94(6):960-6. 
23. Smith PJ, Stevenson J, Chu SY. Associations between childhood vaccination coverage, insurance type, and breaks in health insurance coverage. Pediatrics. 2006;117(6):1972-8.

24. Rosenthal SL, Weiss TW, Zimet GD, Ma L, Good MB, Vichnin MD. Predictors of HPV vaccine uptake among women aged 19-26: importance of a physician's recommendation. Vaccine. 2011;29(5):890-5. doi: 10.1016/j.vaccine.2009.12.063.

25. U.S. Department of Health and Human Services. About the Law [Internet]. 2013 [cited 2013 Oct 15]. Available from: http://www.hhs.gov/healthcare/rights/index.html.

26. American Cancer Society. Human Papilloma Virus (HPV), Cancer, HPV Testing, and HPV Vaccines [Internet]. 2013 [cited 2013 Oct 1]. Available from: http://www.cancer.org/cancer/cancercauses/othercarcinogens/infectiousagents/hpv/huma npapillomavirusandhpvvaccinesfaq/hpv-faq-vaccine-cost.

27. Kaiser Family Foundation. The HPV Vaccine: Access and Use in the U.S [Internet]. 2013 [cited 2013 Dec 5]. Available from: http://kff.org/womens-health-policy/fact-sheet/thehpv-vaccine-access-and-use-in.

28. Centers for Disease Control and Prevention (CDC). Immunization Grant Program (Section 317) [Internet]. 2007 [cited 2013 Dec 5]. Available from: http://www.cdc.gov/vaccines/programs/vfc/downloads/grant-317.pdf.

29. U.S. Department of Health and Human Services (DHHS). Biden Announces \$2.3 Billion in Recovery Act Funds to Help Care for Children, Prevent Disease [Internet]. 2009 [cited 2013 Dec 5]. Available from: http://www.hhs.gov/news/press/2009pres/04/20090409a.html.

30. Centers for Disease Control and Prevention (CDC). Advisory Commitee on Immunization Practices (ACIP): Quadrivalent Human Papillomavirus Vaccine [Internet]. 2007 [cited 2013 Oct 1]. Available from: http://www.cdc.gov/mmwr/preview/mmwrhtml/rr5602a1.htm.

31. National Center for Immunization and Respiratory Diseases. How Vaccines Prevent Disease [Internet]. 2012 [cited 2013 Oct15]. Available from: http://www.cdc.gov/vaccines/vac-gen/howvpd.htm\#why.

32. National Center for Immunization and Respiratory Diseases. Vaccines and Preventable Diseases: HPV Vaccine - Questions \& Answers [Internet]. 2012 [cite 2013 Oct 1]. Available from: http://www.cdc.gov/vaccines/vpd-vac/hpv/vac-faqs.htm.

33. Centers for Medicare \& Medicaid Services. Children's Health Insurance Program (CHIP) [Internet]. 2013 [cited 2013 October 1]. Available from: http://www.medicaid.gov/Medicaid-CHIP-Program-Information/By-Topics/ChildrensHealth-Insurance-Program-CHIP/Childrens-Health-Insurance-Program-CHIP.html. 
34. Kaiser Family Foundation. Preventive Services Covered by Private Health Plans under the Affordable Care Act [Internet]. 2011 [cited 2013 Dec 5 2013]. Available from: http://kff.org/health-reform/fact-sheet/preventive-services-covered-by-private-healthplans.

35. U.S. Government Printing Office (GPO). H.R.3590: An Act Entitled The Patient Protection and Affordable Care Act [Internet]. 2010 [cited 2013 Dec 5]. Available from: http://www.gpo.gov/fdsys/pkg/BILLS-111hr3590enr/pdf/BILLS-111hr3590enr.pdf.

36. Democratic Policy \& Communications Center (DPCC). The Patient Protection and Affordable Care Act Section-by-Section Analysis [Internet]. 2010 [cited 2013 December 5]. Available from: http://www.dpc.senate.gov/healthreformbill/healthbill05.pdf.

37. Kaiser Family Foundation. The Requirement to Buy Coverage Under the Affordable Care Act [Internet]. 2013 [cited 2013 Dec 5]. Available from:

$\mathrm{http}: / / \mathrm{kff}$.org/infographic/the-requirement-to-buy-coverage-under-the-affordable-care-act.

38. Moy B, Polite B, Halpern M, Stranne S, Winer E, Wollins D, Newman L. American Society of Clinical Oncology Policy Statement: Opportunities in the Patient Protection and Affordable Care Act to Reduce Cancer Care Disparities. American Society of Clinical Oncology. 2011;29(28): 3816-3824. doi: 10.1200/JCO.2011.35.8903.

39. Rosenbaum S. The Patient Protection And Affordable Care Act: Implications For Public Health Policy And Practice. Public Health Reports. 2011;126.

40. Penchansky R, Thomas JW. The Concept of Access: Definition and Relationship to Consumer Satisfaction. Medical Care. 1981;19(2):127-140.

41. Centers for Disease Control and Prevention. About the National Immunization Survey [Internet]. 2013 [cited 2013 Oct 15]. Available from: http://www.cdc.gov/nchs/nis/about_nis.htm.

42. Centers for Disease Control and Prevention. Data User's Guide for the 2011 NIS-Teen Public-Use Data File. The 2011 National Immunization Survey - Teen [Data file]. 2012 [cited 2013 Oct 15]. Available from: $\mathrm{ftp} / /$ ftp.cdc.gov/pub/Health_Statistics/NCHS/Dataset_Documentation/NIS/NISteenPUF1 1_DUG.pdf.

43. Merck \& Co., Inc. Highlights of Prescribing Information: Gardasil [Internet]. 2011 [cited 2013 Oct 15]. Available from: http://www.merck.com/product/usa/pi_circulars/g/gardasil/gardasil_pi.pdf.

44. GlaxoSmithKline Biologicals. Highlights of Prescribing Information: Cervarix [Internet]. 2011 [cited 2013 Oct 15]. Available from: http://us.gsk.com/products/assets/us_cervarix.pdf. 
45. National Center for Health Statistics. Summary of NCHS Surveys and Data Collection Systems [Internet]. 2012 [cited 2013 Oct 31]. Available from:

http://www.cdc.gov/nchs/data/factsheets/factsheet_summary.htm.

46. National Center for Health Statistics. How NCHS Protects Your Privacy: Confidentiality and Security of Information Collected by The National Center for Health Statistics [Internet]. 2012 [cited 2013 Oct 30]. Available from: http://www.cdc.gov/nchs/about/policy/confidentiality.htm.

47. Luman E, Barker L, Shaw K, McCauley M, Buehler J, Pickering L. Timeliness of Childhood Vaccinations in the United States. JAMA. 2005;293 (10):1204-1211.

48. U.S. Census Bureau. CPS Health Insurance Definitions [Internet]. 2012 [cited 2014 Mar 12]. Available from:

http://www.census.gov/hhes/www/hlthins/methodology/definitions/cps.html.

49. Jain N, Euler GL, Shefer A, Lu P, Yankey D, Markowitz L. Human papillomavirus (HPV) awareness and vaccination initiation among women in the United States, National Immunization Survey-Adult 2007. Prev Med. 2009;48(5): 426-31. doi: 10.1016/j.ypmed.2008.11.010.

50. Mast E, Margolis HS, Fiore AE, Brink EW, Goldstein ST, Wang SA, Moyer LA, Bell BP, Alter MJ, Advisory Committee on Immunization Practices (ACIP). A comprehensive immunization strategy to eliminate transmission of hepatitis $B$ virus infection in the United States: recommendations of the Advisory Committee on Immunization Practices (ACIP) part 1: immunization of infants, children, and adolescents [Internet]. MMWR Recomm Rep. 2005;54(RR-16):1-31. Available from: http://www.cdc.gov/mmwr/preview/mmwrhtml/rr5416a1.htm

51. Coronado VG, Maes EF, Rodewald LE, Chu S, Battaglia MP, Hoaglin DC, Merced NL, Yusuf H, Cordero JF, Orenstein WA. Risk factors for underimmunization among 19-35 month-old children in the United States: National Immunization Survey, July 1996-June 1998. Unpublished manuscript cited in 2011 NIS- Teen PUF Data User's Guide. Centers for Disease Control and Prevention, Atlanta. 2000 [cited 2013 Nov 1]. Available from:

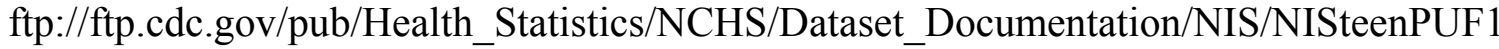
1_DUG.pdf

52. Hoff T, Greene L, Davis J. National Survey of Adolescents and Young Adults: Sexual Health Knowledge, Attitudes and Experiences [Internet]. Menlo Park, CA: Henry J. Kaiser Family Foundation; 2003 [cited 2013 Oct 15]. Available from: http://kff.org/hivaids/report/national-survey-of-adolescents-and-young-adults.

53. National Center for Health Statistics. Frequently Asked Questions for the National Immunization Survey: Why does the study request information from medical providers? [Internet]. 2013 [cited 2013 Nov 2]. Available from: http://www.cdc.gov/nchs/nis/nis_faq.htm\#WHY\%20MEDICAL\%20PROVIDER. 
54. Smith PJ, Stevenson J, Chu SY. Associations between childhood vaccination coverage, insurance type, and breaks in health insurance coverage. Pediatrics. 2006;117(6):1972-8.

55. Smith LM, Brassard P, Kwong JC, Deeks SL, Ellis AK, Lévesque LE. Factors associated with initiation and completion of the quadrivalent human papillomavirus vaccine series in an Ontario cohort of grade 8 girls. BMC Public Health. 2011;11:645. doi: 10.1186/14712458-11-645.

56. Paul L. Reiter, Melissa B. Gilkey, Noel T. Brewer. HPV vaccination among adolescent males: Results from the National Immunization Survey-Teen, Vaccine. 2013;31(26:28162821, ISSN 0264-410X. Available from: http://dx.doi.org/10.1016/j.vaccine.2013.04.010.

57. Jain N, Singleton JA, Montgomery M, Skalland B. Determining accurate vaccination coverage rates for adolescents: the National Immunization Survey-Teen 2006. 2009; 124(5):642-51. Available from: http://www.ncbi.nlm.nih.gov/pmc/articles/PMC2728656.

58. Bryant CM. Understanding the intersection of race and marriage: Does one model fit all? Psychological Science Agenda. American Psychological Association. 2010 [cited 2014 April 7]. Available from: https://www.apa.org/science/about/psa/2010/10/racemarriage.aspx.

59. Jolley D, Douglas KM. The Effects of Anti-Vaccine Conspiracy Theories on Vaccination Intentions. PLoS ONE. 2014;9(2):e89177. doi:10.1371/journal.pone.0089177.

60. Behrmann J. The anti-vaccination movement and resistance to allergen-immunotherapy: a guide for clinical allergists. Allergy, Asthma \& Clinical Immunology. 2010;6:26. doi:10.1186/1710-1492-6-26.

61. Buettgens M, Hall MA. Who Will be Uninsured After Health Insurance Reform? Urban Institute. 2014 [cited 20 April 2014]. Available from: http://www.rwjf.org/en/researchpublications/find-rwjf-research/2011/03/who-will-be-uninsured-after-health-insurancereform-.html.

62. Dorell C, Yankey D, Jeyarajah J, Stokley S, Fisher A, Markowitz L, Smith P J. Delay and Refusal of Human Papillomavirus Vaccine for Girls, National Immunization SurveyTeen, 2010. Clinical pediatrics. 2014. doi:0009922813520070.

63. Bednarczyk RA, Curran EA, Orenstein WA, Omer SB Health Disparities in Human Papillomavirus Vaccine Coverage: Trends Analysis From the National Immunization Survey-Teen, 2008-2011. Clinical Infectious Diseases. 2014;58(2):238-241.

64. Hofstetter AM, Stockwell MS, Al-Husayni N, Ompad D, Natarajan K, Rosenthal S L, Soren K. HPV vaccination: Are we initiating too late?. Vaccine. 2014;32(17):1939-1945. 
65. Jeudin P, Liveright E, del Carmen MG, Perkins RB. Race, Ethnicity, and Income Factors Impacting Human Papillomavirus Vaccination rates. Clinical therapeutics. 2014;36(1): 24-37.

66. Rambout L, Tashkandi M, Hopkins L, Tricco AC. Self-reported barriers and facilitators to preventive human papillomavirus vaccination among adolescent girls and young women: A systematic review. Preventive medicine. 2014;58:22-32.

67. Smith PJ, Chu SY, Barker LE. Children who have received no vaccines: who are they and where do they live?. Pediatrics. 2004;114(1):187-195.

68. Lincoff N. Study: Two Doses of HPV Vaccine as Effective as Three. Healthline News: 2014 [cited 2014 April 25]. Available from: http://www.healthline.com/healthnews/children-two-doses-hpv-vaccine-effective-three-043013.

69. Herweijer E, Leval A, Ploner A, et al. Association of Varying Number of Doses of Quadrivalent Human Papillomavirus Vaccine With Incidence of Condyloma. JAMA. 2014;311(6):597-603. doi:10.1001/jama.2014.95.

70. Dobson SR, McNeil S, Dionne M, Dawar M, Ogilvie G, Krajden M, ... Young E. Immunogenicity of 2 Doses of HPV Vaccine in Younger Adolescents vs 3 Doses in Young WomenA Randomized Clinical TrialImmunogenicity of HPV Vaccine in Girls vs Women. JAMA. 2013;309(17), 1793-1802.

71. Katz MH. Health Insurance Is Not Health Care. JAMA internal medicine. 2014. Available from: http://archinte.jamanetwork.com/article.aspx?articleID=1857087\&utm_source=dlvr.it\&ut $\mathrm{m} \_$medium $=$twitter\&utm_campaign $=$feed_posts.

72. National Cancer Institute (NCI). Human Papillomavirus (HPV) Vaccines: Should the vaccines be given to people who are already infected with HPV? 2011 [cited 2014 May 26]. Available from: http://www.cancer.gov/cancertopics/factsheet/prevention/HPVvaccine.

73. U.S. Centers for Medicare \& Medicaid Services. What are my preventive care benefits? 2011. Available from: https://www.healthcare.gov/what-are-my-preventive-carebenefits/\#part=3.

74. Centers for Disease Control and Prevention (CDC). National and State Vaccination Coverage Among Adolescents Aged 13-17 Years - United States, 2012. MMWR Morb Mortal Wkly Rep. 2013 Sep 13;62(36):733-40. Available from: http://www.cdc.gov/mmwr/preview/mmwrhtml/mm6234a1.htm.

75. Partnership for Prevention. Preventive Care: A National Profile on Use, Disparities, and Health Benefits. 2007. Available from: http://www.rwjf.org/content/dam/farm/reports/reports/2007/rwjf13325. 
76. Multuck M. Use of Clinical Preventive Services and Prevalence of Health Risk Factors Among Adults Aged 50-64: National and State-Level Racial/Ethnic, Socioeconomic, and Health Insurance Coverage Status Disparities. AARP Public Policy Insitute. 2013. Available from: http://www.aarp.org/health/health-insurance/info-08-2013/use-ofclinical-preventive-services-and-prevalence-AARP-ppi-health.html.

77. Agency for Healthcare Research and Quality (AHRQ). Disparities in Healthcare Quality Among Racial and Ethnic Groups: Selected Findings from the 2011 National Healthcare Quality and Disparities Reports. Fact Sheet. 2012 Sep. Available from: http://www.ahrq.gov/qual/nhqrdr11/nhqrdrminority11.htm.

78. National Network for Immunization Information (NNii). Why is Hepatitis B Immunization Recommended for All Infants, Children, and Adolescents? 2008. Available from: http://www.immunizationinfo.org/issues/general/why-hepatitis-b-immunizationrecommended-all-infants-children-and-adolescents. 